\title{
Conceptual confusing similarity and pictorial trade marks
}

\author{
Rob Batty* \\ Faculty of Law, University of Auckland
}

Several high-profile rebrands, including those by Twitter and Starbucks, have involved removing text from logos. This move towards wordless, pictorial trade marks raises a difficult question about how the scope of protection of a registered trade mark should be determined. This article examines the particular issue of how much weight should be given to the idea or concept underlying a pictorial mark when assessing whether a defendant's junior mark is 'confusingly similar'. Drawing on legal principles and case examples from Europe, the United Kingdom, Singapore and New Zealand, it is claimed that courts and adjudicators should be careful not to overweight conceptual similarity. It is argued that a lack of care in assessing conceptual similarity risks awarding one trader overbroad protection, which may be tantamount to conferring on one trader a monopoly in an idea. A lack of care may also undermine the logic of a registration system by untethering protection from what is recorded on the Register, and may make trade mark law less predictable and certain.

Keywords: trade mark law, likelihood of confusion, pictorial marks, conceptual similarity, idea of a mark, Europe, United Kingdom, Singapore, New Zealand

\section{INTRODUCTION}

In 2011, the Starbucks logo changed. The words 'Starbucks Coffee' were removed. ${ }^{1}$ Starbucks' re-branding of its logo to remove text is consistent with an apparent trend towards wordless logos. ${ }^{2}$ Wordless, pictorial logos may be 'loved by marketers', but they also present some difficult questions for registered trade mark law. ${ }^{3}$ One particularly difficult question is determining the appropriate scope of protection for a pictorial registered trade mark.

In jurisdictions with trade mark legislation dictated or influenced by the European Trade Marks Directive (such as the United Kingdom, New Zealand and Singapore), the boundary of a registered trade mark's scope of protection is dictated by reference to the prospect of consumer confusion. A registered trade mark owner has a cause of

* The author declares that he was junior counsel in a case discussed in this article, Carabao Tawandang Co Ltd v Red Bull GmbH HC Wellington CIV-2005-485-1975, 31 August 2006. The views represented in this article are the author's own, and do not reflect the views of his employer at the time, or the views of the client represented in that particular case.

1. Michelle Flandreau, 'Who is the Starbucks Siren?' (23 December 2016) <https://stories. starbucks.com/stories/2016/who-is-starbucks-siren/> (last accessed 19 November 2020).

2. See for example, Kalle Oskari Mattila, 'The Age of the Wordless Logo', The Atlantic (8 September 2016) <https://www.theatlantic.com/business/archive/2016/09/the-age-of-thewordless-logo/499166/> (last accessed 19 November 2020).

3. James Nurton, 'Trade Marks that are Famous but Nameless' (2013) 231 Managing Intellectual Property 4. 
action for trade mark infringement where another trader uses a sign (a junior mark) in a way which gives rise to a likelihood of confusion. What degree of similarity between a junior mark and a senior registered trade mark is sufficient to give rise to a likelihood of confusion in a given case is not determinable a priori, and depends on a range of factors. ${ }^{4}$ Courts, in particular, take into account visual, aural and conceptual similarity between the senior registered trade mark and the junior mark used by the defendant.

This article examines the role of conceptual similarity in determining whether a junior mark is 'confusingly similar' to a pictorial and textless registered trade mark (which is referred to as a 'pictorial mark'). Conceptual similarity is similarity in the semantic meaning or the ideas of trade marks. It is claimed that courts and adjudicators should be careful not to overweight conceptual similarity in determining whether use of a junior mark gives rise to a likelihood of confusion. The article argues that a lack of circumspection in assessing conceptual similarity may award a pictorial mark an overly broad scope of protection in a particular commercial sphere, and raise concerns about one trader gaining a monopoly in an idea. It may also risk underweighting or ignoring significant visual differences in the way marks present the same subject matter. A lack of care may also undermine the logics of a registration system, untethering the scope of protection from what is recorded on the Register, and may make the law less predictable and certain.

The argument of this article is presented by making reference to United Kingdom, Singapore and New Zealand trade mark law. It is recognized that broad generalized claims across different jurisdictions would be difficult to substantiate, particularly in such a context-specific area of the law. Therefore, the approach of this article is deliberately instrumental. The article identifies and uses illustrative cases from across jurisdictions to make generalizable insights about how the scope of protection given to a pictorial mark should be assessed.

The article begins in section 2 by outlining reasons for the trend towards pictorial marks. It briefly considers the nature of the rights acquired by a registered trade mark, and how the scope of such rights is determined. This is necessary background to understand section 3, which examines the principles that have been developed to ascertain whether two trade marks are confusingly similar. Section 3 further explains how the idea of a mark is taken into account in determining confusing similarity. Section 4 , through a series of illustrative cases, demonstrates how and why adjudicators should be careful in giving significant weight to conceptual similarity when assessing the overall similarity between a senior registered trade mark and a junior mark. Section 5 considers some potential caveats to the arguments presented. Section 6 concludes.

\section{PICTORIAL TRADE MARKS AND THE NATURE OF THE RIGHTS CONFERRED BY A TRADE MARK REGISTRATION}

\subsection{Wordless pictorial trade marks}

Trade marks are generally categorized by type. 'Figurative' or 'device' marks describe registered trade marks that are presented using images and words, stylized words, or simply images alone. 'Word marks' describe registered trade marks in a plain word

4. Seixo v Provezende [1865] LR 1 Ch App 192 at 196. The question of 'mark-similarity' has been described as 'more of an art than a science, more of feel than of formula', see Choice Fortune Holdings Limited v Seiko Holdings Kabushiki Kaisha [2014] SGIPOS 8 at 37. See also The European Ltd $v$ The Economist Newspaper Ltd [1998] FSR 283 at 288: 'similarity is a matter of degree'. 
format. There are other types. ${ }^{5}$ Word marks are the most prevalent type of trade mark application. For example, in Europe in 2019, 53 per cent of all trade mark applications were for word marks, and 46.44 per cent were for figurative marks. ${ }^{6}$

Figurative, word-free, pictorial marks have always been popular in certain visually dominated industries such as clothing. For example, consider Lacoste's crocodile logo, Ralph Lauren's polo player logo and Puma's leaping puma logo. Some larger corporations have also long used pictorial marks. For instance, Target and its three ringed logo, McDonalds and its golden arches, and Shell and its pecten (or scallop) shell. Anecdotal reports also suggest that more corporations are opting to strip the text from their logos. ${ }^{7}$ Recent examples include Mastercard removing the text from its overlapping red and yellow balls logo and Twitter removing the text from its bird logo.

Evamy has argued that the use of pictorial marks is a sign of increased visual literacy in society and reflects the unique power of visual symbols: ${ }^{8}$

Symbols on their own are more powerful - or offer an impression of greater power - than symbols that require a supporting text. They can develop the capacity to trigger complex collections of feelings, bypassing the conscious mind on the way. And they are more exportable; they more easily avoid associations with specific cultures or languages.

As Evamy intimates, and as those writing from a marketing perspective have identified, pictorial marks may be better at crossing language divides. ${ }^{9}$ The trend towards removing text may also reflect how the public are now more comfortable and more adept at communicating without text or words, such as with emojis and gifs. ${ }^{10}$

The trend towards the adoption of pictorial marks may also reflect fundamental changes to the modern economy and the way in which goods and services are now marketed and sold. ${ }^{11}$ Pictorial marks are desirable because they work better on apps and are more easily readable on smartwatches and tablets. ${ }^{12}$ In these new marketing environments, space is often limited and this can create issues with the legibility of words. ${ }^{13}$ For example, as well as the Twitter logo, the logos of Instagram and Spotify are now both wordless.

5. For example, '3D', 'colour', 'sound', 'olfactory', though sometimes the nomenclature may differ.

6. EUIPO, 'EUIPO Statistics in European Union Trade Marks' (2020) available from $<$ https://euipo.europa.eu/ohimportal/en/the-office> (last accessed 19 November 2020).

7. See Mattila (n 2); Kyle O'Brien, 'Why Brands Such as Doritos and Mastercard are Removing the Names from their Logo', The Drum (29 August 2019) <https://www.thedrum. com/news/2019/08/29/why-brands-such-doritos-and-mastercard-are-removing-the-names-theirlogos> (last accessed 19 November 2020) and 'Wordless Logos: The Power it Holds and How to Leverage on it' (May 2019) <https://www.logodesignteam.com/blog/wordless-logos/> (last accessed 19 November 2020). More generally, see Michael Evamy, 'World Without Words' (Laurence King Publishing, London 2003) and Ella Chmielewska, 'Logos or the Resonance of Branding: A Close Reading of the Iconosphere of Warsaw' (2004) 8(4) Space and Culture 349, 354-355.

8. Michael Evamy, 'Iconic Boom' (2003) 208 Blueprint 62, 62.

9. C Whan Park, Andreas B Eisingerich and Gratiana Pol, 'The Power of a Good Logo' (2014) 55(2) MIT Sloan Management Review 10, 12.

10. O’Brien (n 7).

11. Mattila (n 2).

12. Ibid.

13. 'A Wordless Future? What Mastercard's New Logo Tells Us about the Modern Brand' (27 January 2019) <https://www.monotype.com/resources/articles/a-wordless-future-what-master card-s-new-logo-tells-us-about-the-modern-brand> (last accessed 19 November 2020). 
It has also been suggested that pictorial marks may help global brands appear less corporate, and therefore, more appealing to modern consumers. ${ }^{14}$ Images, unhindered by words, may promote a more active meaning-making experience for consumers. ${ }^{15}$ Consumers can adopt their own, more personal, interpretations of a logo and its advertising message.

Removing text may also be beneficial in creating flexibility for traders who want to move out of specific areas of business without being associated exclusively with particular products because of words featured in their logo or branding materials. ${ }^{16}$ For example, Apple's original logo (before it moved into product categories beyond computers) featured the words 'Apple Computer Co' and a picture of Isaac Newton. ${ }^{17}$ Similarly, removing the text 'Starbucks Coffee' from Starbucks' logo removed an association solely to coffee, and aligned with Starbucks' marketing strategy of being 'more than just coffee'. ${ }^{18}$

A trader adopting a pictorial mark will naturally want it to be protected against other traders using the same or a similar image. When a pictorial mark is first created and recorded in some form, it is likely that the image will be protected as an artistic work by copyright law. Copyright law will prohibit another trader copying, the whole or a substantial part, of the pictorial mark. Some traders will additionally seek to register the pictorial mark as a trade mark for the additional protection registered trade mark law offers. As the next subsection explains, unlike copyright, registered trade mark protection provides relief against all traders replicating a pictorial mark in the same commercial sphere - not just copyists.

\subsection{The rights provided by a trade mark registration}

Registered trade marks are personal property and like other property rights operate in rem. ${ }^{19}$ A trade mark registration purports to give its owner the exclusive rights to use the trade mark..$^{20}$ Arguably, despite the reference to an exclusive use right, the nature of a property right to a registered trade mark is a 'negative right'. ${ }^{21}$ That is, the nature of the property rights created by a trade mark registration is best considered as a right

\footnotetext{
14. Mattila (n 2).

15. Ibid, quoting an email from Jill Avery, a senior lecturer at Harvard Business School.

16. Ibid.

17. Nick Carson, '6 Famous Textless Logos and Why They Work' Creativebloq (26 February $2019)<$ https://www.creativebloq.com/features/6-famous-textless-logos-and-why-they-work> (last accessed 23 November 2020).

18. Jeremy Raynolds, 'Starbucks Marketing Strategy: It's About More than Just Coffee' PCSkull.com (1 September 2019) <https://www.pcskull.com/starbucks-marketing-strategy/> (last accessed 19 November 2020).

19. Rovio Entertainment Ltd v Kimanis Food Industries Sdn Bhd [2015] SGHC 216, [2015] 5 SLR 618 at para 68.

20. Trade Marks Act 1994 (UK), s 9(1)(a); Trade Marks Act (Cap 332, 1999 Rev Ed) (Singapore), s 26(1)(a); Trade Marks Act 2002 (NZ), s 10(1)(a).

21. See JT International SA v Commonwealth of Australia [2012] HCA 43, (2012) 250 CLR 1 at para 248 per Crennan J citing William Cornish, David Llewelyn and Tanya Aplin, Intellectual Property: Patents, Copyright, Trade Marks and Allied Rights (7th edn, Sweet \& Maxwell, London 2010) 7, para 1-04. See also British American Tobacco UK Ltd v The Secretary of State for Health [2016] EWHC 1169 at paras 737-43.
} 
to exclude others, which is given effect by statutory infringement provisions. ${ }^{22}$ A registered trade mark owner's right to exclude extends to three situations. ${ }^{23}$

First, a registered trade mark owner can exclude a third party using an identical sign to its registered trade mark for exactly the same goods and services as those covered by its registration. ${ }^{24}$ This can be referred to as a trade mark's umbra, or 'core zone of protection'. ${ }^{25}$ The boundary of this zone is firstly set by the trade mark owner's specification of goods or services, and secondly by whether the sign used by the defendant is identical to the registered trade mark. ${ }^{26}$

Second, a trade mark owner can exclude a third party using an identical sign to its registered trade mark in relation to goods or services that are similar to the registered goods or services. A trade mark owner can also exclude a third party using a similar sign to its registered trade mark in relation to goods or services that are identical or similar to the registered goods or services. ${ }^{27}$ In both instances, in order to succeed in an infringement action, the trade mark owner must establish that the third party's use gives rise to a likelihood of confusion. Such a right to exclude can be described as a trade mark owner's penumbra of protection and provides a 'supplementary zone' of protection to the core zone of protection. ${ }^{28}$ The boundary of this supplementary zone is shaped by the similarity/identity of the marks and the similarity/identity of the goods or services, and is ultimately set by a likelihood of confusion test.

In addition to these two main rights of exclusion, a trade mark owner may exclude other third parties in situations where use of an identical or similar sign amounts to, what can broadly be described as, 'dilution'. Under the United Kingdom's Trade Marks Act 1994 (1994 Act) and New Zealand's Trade Marks Act 2002 (2002 Act) it is an infringement if a third party uses an identical or similar sign on goods or services which takes 'unfair advantage of', or would be 'detrimental to', 'the distinctive character or repute' of the registered mark. ${ }^{29}$ This represents an 'additional zone of

22. Inter Lotto (UK) Ltd v Camelot Group Plc [2003] EWHC 1256 (Ch), [2004] RPC 8 at para 35.

23. This has been categorized as a 'triad of protection'; see Joachim Bornkamm, 'Harmonising Trade Mark Law in Europe: The Stephen Stewart Memorial Lecture' (1999) 3 IPQ 283, 293.

24. Trade Marks Act 1994 (UK), s 10(1); Trade Marks Act (Cap 332, 1999 Rev Ed) (Singapore), s 27(1); Trade Marks Act 2002 (NZ), s 89(1)(a).

25. See Andrew Griffiths, 'The Trade Mark Monopoly: An Analysis of the Core Zone of Absolute Protection Under Art 51(A)', (2007) 3 IPQ 312, 313, Crocodile International PTE Ltd v Lacoste [2017] NZSC 14, [2017] 1 NZLR 679 at para 46 and ANIMAL Trade Mark [2003] EWHC $1589(\mathrm{Ch})$, [2014] FSR 19 at para 20.

26. On the strict approach to what constitutes 'identical', see Case C-291/00 LTJ Diffusion SA $v$ Sadas Vertbaudet SA [2003] ECR I-02799, ECLI:EU:C:2003:169. This has been followed in Singapore in City Chain Stores (S) Pte Ltd v Louis Vuitton Malletier [2009] SGCA 53, [2010] FSR 14 and in New Zealand in InterCity Group (NZ) Ltd v Nakedbus NZ Ltd [2014] NZHC 124, [2014] 3 NZLR 177.

27. Trade Marks Act 1994 (UK), s 10(2); Trade Marks Act (Cap 332, 1999 Rev Ed) (Singapore), s 27(2); Trade Marks Act 2002 (NZ), s 89(1)(b) and s 89(1)(c). New Zealand legislation refers to use that 'would be likely to deceive or confuse'. Confusion is a broader concept than deception in the sense that a person can be confused without being deceived, see New Zealand Breweries Ltd v Heineken's Bier Browerij Maatschappij NV [1964] NZLR 115 at 142. Given the broader scope of confusion, I refer simply to a 'likelihood of confusion' throughout the article.

28. Griffiths (n 25) 314.

29. Trade Marks Act 1994 (UK), s 10(3); Trade Marks Act 2002 (NZ), s 89(1)(d). But note that s 89(1)(d) explicitly refers to 'any goods or services that are not similar to the goods or 
protection' - but only for marks with a reputation (under the 1994 Act) or well-known trade marks (under the 2002 Act). Singapore trade mark law gives effect to dilution protection in a slightly different, and more convoluted fashion, than New Zealand and United Kingdom legislation. ${ }^{30}$

The focus in this article is on the 'supplementary zone of protection' of a registered trade mark, which, as noted above, is shaped by a likelihood of confusion test. The likelihood of confusion test also informs the operation of 'relative grounds of refusal' of a trade mark application under the trade mark laws of the United Kingdom, Singapore and New Zealand. A registered trade mark owner can prevent the same or a similar trade mark from being registered by a third party on grounds that largely mirror the infringement proceedings mentioned above. ${ }^{31}$ In particular, a trade mark owner can object to the registration of a similar trade mark for identical or similar goods and services (junior mark), where there exists a likelihood of confusion. ${ }^{32}$ The same legal principles that determine whether an infringement has occurred are also relevant under these relative grounds of refusal. Accordingly, some of the cases discussed in this article arise in the context of oppositions to registration.

Although the same principles that determine infringement also apply when evaluating whether a relative grounds of refusal exists, the principles are applied in a more abstract way, and the assessment is largely 'paper based'. ${ }^{33}$ This is because in an infringement action, a court considers the actual use of the junior mark by the defendant. However, in determining whether a relative ground of refusal exists, the analysis is based on notional use of the trade mark contained in the application. The Court of Justice of the European Union (CJEU) in O2 Holdings Ltd v Hutchinson $3 G$ Ltd explained the nature of this notional assessment as follows: ${ }^{34}$

Once a mark has been registered its proprietor has the right to use it as he sees fit so that, for the purposes of assessing whether the application for registration falls within the ground for refusal ... it is necessary to ascertain whether there is a likelihood of confusion with the opponent's earlier mark in all the circumstances in which the mark applied for might be used if it were to be registered.

services in respect of which the trade mark is registered'. It is unclear whether a New Zealand court would follow the CJEU guidance in Case C 408/01 Adidas-Salomon AG and Adidas Benelux BV v Fitnessworld Trading Ltd [2003] ECR I-12537, ECLI:EU:C:2003:582 at para 20 and hold that protection must be extended to situations where a defendant's use is in relation to similar or identical goods or services. Also, it should be noted that s 10(3) of the Trade Marks Act 1994 (UK) requires that the use is 'without due cause'.

30. See Trade Marks Act (Cap 332, 1999 Rev Ed) (Singapore), s 8(3) and (4), s 27(3) and s 55. See generally Tee Jim Tan SC, Law of Trade Marks and Passing Off in Singapore (3rd edn, Sweet \& Maxwell, London 2014) 123-79 and 631-4.

31. Under the Trade Marks Act 2002 (NZ), s 25(1)(c), though, the 'anti-dilution' relative ground is not as broad as the infringement provision, s $89(1)(d)$.

32. Trade Marks Act 1994 (UK), s 5(2); Trade Marks Act (Cap 332, 1999 Rev Ed) (Singapore), s 8(2); Trade Marks Act 2002 (NZ), s 25(1)(b). In contrast to the United Kingdom, in New Zealand and Singapore examiners at the relevant Intellectual Property Office will use these relative grounds of refusal to lodge official objections to trade mark applications being accepted for registration.

33. Ilanah Fhima and Dev S Gangjee, The Confusion Test in European Trade Mark Law (Oxford University Press 2019) 188.

34. Case C-533/06 O2 Holdings Ltd v Hutchison 3G UK Ltd [2008] ECR I-04231, ECLI:EU: C:2008:339 at para 66. See also Staywell Hospitality Group Pty Ltd v Starwood Hotels \& Resorts Worldwide, Inc [2013] SGCA 65, [2014] 1 SLR 911 at paras 56-61. 


\subsection{Assessing a likelihood of confusion}

Confusion can be defined as a mental state or scenario that mixes up the mind of a person or one which is perplexing and causes a person to wonder about a state of affairs. ${ }^{35}$ The question whether a junior mark gives rise to a likelihood of confusion has been linked to the essential function of a trade mark as a guarantee of the origin of goods or services. ${ }^{36}$ Accordingly, the CJEU has said that a likelihood of confusion occurs "where the public can be mistaken as to the origin of the goods or services in question'. ${ }^{37}$

Such confusion could occur where the public can mistake the junior mark for the registered trade mark and therefore can mistake one product for another. ${ }^{38}$ Actionable confusion may also be more indirect; that is, where the public can make a mistaken assumption that there is an organizational connection or economic link between the trader marketing products under the junior mark and the trader marketing products under the senior registered trade mark. ${ }^{39}$ For example, consumers may think one trader has decided to expand the range of trade marks it uses on a particular product line. ${ }^{40}$ However, actionable confusion does not include situations where the junior mark merely 'calls to mind' the senior registered trade mark. ${ }^{41}$

In SABEL v Puma, the CJEU further said that whether there is a likelihood of confusion must 'be appreciated globally, taking into account all factors relevant to the circumstances'. ${ }^{2}$ This so-called 'global' assessment involves consideration of the ${ }^{43}$

... recognition of the trade mark on the market, of the association which can be made with the used or registered sign ... the degree of similarity between the trade mark and sign and between the goods or services identified.

The United Kingdom Trade Mark Registry and the English courts have further extrapolated various matters from the CJEU's case law into a set of factors that should be taken into account when applying the likelihood of confusion test. ${ }^{44}$

One of the relevant factors identified is the distinctive character of the senior registered trade mark. ${ }^{45}$ 'Distinctive character' in this context means the capacity of the registered trade mark to function as a badge of origin for particular goods or services. ${ }^{46}$ The quality of distinctiveness is typically used in "contradistinction to descriptiveness' ${ }^{47}$ The distinctiveness of word marks, is, therefore, usually conceptualized across

35. See Pioneer Hi-Bred Corn Company v Hy-Line Chicks Pty Ltd [1978] 2 NZLR 50 at 62. 36. See Case C-39/97 Canon Kabushiki Kaisha v MGM Inc [1998] ECR I-05507, ECLI:EU: C:1998:442 at paras 27-8.

37. Ibid at para 26.

38. See Case C-251/95 SABEL BV v Puma AG, Dassler Sport [1997] ECR I-06191, ECLI:EU: C:1997:528 at para 16 and Opinion of AG Jacobs at para 38.

39. Ibid.

40. Hai Tong Co (Pte) Ltd v Ventree Singapore Pte Ltd [2013] SGCA 26, [2013] 2 SLR 941 at para 74.

41. SABEL v Puma (n 38) at para 18; Hai Tong (n 40) at para 75.

42. SABEL v Puma (n 38) at para 22.

43. Ibid.

44. See Specsavers International Healthcare Ltd v Asda Stores Ltd [2012] EWCA Civ 24, [2012] FSR 19 at para 52; Maier v ASOS Plc [2015] EWCA Civ 2020, [2015] FSR 20 at paras 75-6.

45. SABEL v Puma (n 38) at para 24 and Canon (n 36) at para 18.

46. See Staywell (n 34) at para 24.

47. Ibid. 
a spectrum. Trade marks with a 'weak' distinctive character are often those which are descriptive or laudatory in regard to particular goods or services. Trade marks with a strong distinctive character may be invented words and words without meaning in regard to particular goods or services. Distinctiveness is relevant because the CJEU has said that the more distinctive the senior registered trade mark, the greater the prospect of a likelihood of confusion. ${ }^{48}$ Accordingly, a registered trade mark with a higher level of distinctiveness is thought to have 'broader protection' via the supplementary zone of protection than a trade mark with a lower level of distinctiveness. ${ }^{49}$

One doctrinal issue across jurisdictions is whether similarity of marks and similarity of goods or services should be seen as sequential and threshold requirements that must be satisfied before considering whether a likelihood of confusion exists. The jurisprudence of the CJEU seems to present two conflicting ideas. In Vedial v OHIM the CJEU suggested that the similarity of marks and the similarity of goods or services were 'cumulative' requirements, and needed to be satisfied before considering a likelihood of confusion. ${ }^{50}$ However, in the earlier Canon $v M G M$ case, the CJEU identified that under a global assessment approach there can be an interdependence between relevant factors, and particularly between the similarity of goods or services and the similarity of marks. ${ }^{51}$ The CJEU further said 'a lesser degree of similarity between [the] goods or services may be offset by a greater degree of similarity between the marks, and vice versa' ${ }^{52}$

English courts initially favoured a sequential approach, ${ }^{53}$ before following the 'interdependence principle' and the 'global assessment' approach outlined in Canon $v M G M .{ }^{54}$ Singapore courts have continued to favour what they have referred to as a 'step-by-step' approach, where a similarity of marks and goods/services needs to be answered affirmatively before progressing to consider a likelihood of confusion 'in the round'. ${ }^{55}$ New Zealand's courts have tended to apply a step-by-step approach, but not uniformly. ${ }^{56}$

It is unlikely that there is any material difference between the 'global assessment' approach and the 'step-by-step approach'. The Singapore Court of Appeal in The Polo/ Lauren Co, LP v Shop-In Department Store Pte Ltd doubted whether the end result would be different under the 'step-by-step' approach or the 'global assessment' approach. ${ }^{57}$ The New Zealand Court of Appeal has also observed: ${ }^{58}$

\footnotetext{
48. SABEL v Puma (n 38) at para 24.

49. Canon (n 36) at para 18.

50. Case C-106/03 P Vedial v OHIM [2004] ECR I-09573, ECLI:EU:C:2004:611, at para 51.

51. Canon (n 36) at para 17.

52. Ibid at para 17.

53. See British Sugar PLC v James Robertson \& Sons Ltd [1996] RPC 281 at 294-5.

54. See Reed Executive Plc v Reed Business Information Ltd [2004] EWCA Civ 159, [2004] RPC 767 at paras 79 and 95 and L'Oréal SA v Bellure NV [2006] EWHC 2355 (Ch), [2007] RPC 14 at para 117.

55. See Staywell (n 34) at para 15 and Richemont International SA v Goldlion Enterprise (Singapore) Pte Ltd [2005] SGHC 208, [2006] 1 SLR 401 at paras 21-4.

56. See Intellectual Reserve Inc v Sintes HC Auckland, CIV-2007-404-2610, 13 December 2007 at paras 14-15 and N V Sumatra Tobacco Trading Co v New Zealand Milk Brands Ltd [2011] NZCA 264, [2011] 3 NZLR 206 at para 32. But compare N V Sumatra Tobacco Trading Co v British American Tobacco (Brands) Inc [2010] NZCA 24, (2010) 86 IPR 206 and Prada $v$ The Farmers Trading Co Ltd HC Auckland CIV-2010-485-58, 21 September 2010. 57. Polo/Lauren Co, LP, The v Shop-In Department Store Pte Ltd [2006] SGCA 14, [2006] 2 $\operatorname{SLR}(\mathrm{R}) 690$ at para 9.

58. N V Sumatra Tobacco Trading Co v British American Tobacco (n 56) at para 18.
} 
In our view the differences in approach between the parties really amount to semantics. There will be an overall global assessment of the inter-dependent questions ... However, it is likely that the questions (as well as the other factors referred to ...) would usually be considered and answered separately in the course of the making of the global assessment.

As the Singapore High Court observed in Nation Fittings, what must create an actionable likelihood of confusion is similarity between marks. ${ }^{59}$ Such similarity may be considered to be weak or strong, but some similarity must be present. If there is "no similarity at all' between the marks 'there is no likelihood of confusion to be considered'. ${ }^{60}$

\section{DETERMINING SIMILARITY BETWEEN PICTORIAL MARKS}

\subsection{General method for determining similarity between marks}

In SABEL v Puma, the CJEU also provided guidance on how similarity between a senior registered trade mark and a junior mark should be conducted. It stated: ${ }^{61}$

That global appreciation of the visual, aural or conceptual similarity of the marks in question, must be based on the overall impression given by the marks, bearing in mind, in particular, their distinctive and dominant components.

The phrase 'distinctive and dominant' in this context means something different from the term 'distinctive character' referred to above. ${ }^{62}$ The phrase 'distinctive and dominant' intimates that there may be particular elements of a trade mark which are 'outstanding', 'memorable' or which stand out when a consumer perceives the trade mark. ${ }^{63}$ The Singapore Court of Appeal has dubbed this 'non-technical' distinctiveness. ${ }^{64}$ The non-technical distinctiveness of an element of a trade mark could depend on the size of the element or how the element is positioned within a trade mark. ${ }^{65}$ The non-technical distinctiveness of an element may also overlap with its 'technical' distinctiveness. This is because what may make a component of a trade mark stand out and be noticed by consumers could be its 'technical' distinctiveness (generally, its non-descriptiveness) - for example, if a trade mark contains an invented word. By contrast, descriptive or commonplace elements are unlikely to make a memorable impression. ${ }^{66}$

59. Nation Fittings (M) Sdn Bhd v Oystertec Plc and Another Suit [2005] SGHC 225, [2006] $1 \mathrm{SLR}(\mathrm{R}) 712$ at para 95.

60. esure Insurance v Direct Line Insurance [2008] EWCA Civ 842, [2008] RPC 34 at para 49. See also The Coca-Cola Company v Frucor Soft Drinks Ltd [2013] NZHC 3282, (2013) 104 IPR 432 at para 154.

61. SABEL v Puma (n 38) at para 23.

62. Case C-235/05 L'Oréal SA v OHIM [2006] ECR I-00057, ECLI:EU:C:2006:271 at para 43 and Staywell (n 34) at para 22 referring to Bud and Budweiser Budrau Trade Marks [2002] EWCA Civ 1534, [2003] RPC 25 at para 39.

63. Staywell (n 34) at para 23.

64. Ibid.

65. Fhima and Gangjee (n 33) 73.

66. Bud and Budweiser Budrau Trade Marks (n 62) at para 39. See also The Coca-Cola Company of Canada Ltd v Pepsi-Cola Company of Canada Ltd (1942) 59 RPC 127 at 134: 
This notion that certain dominant and distinctive elements stand out to consumers when they perceive a trade mark flows from trade mark law's evocation of the 'average consumer'. In Lloyd Schuhfabrik the CJEU said that the assessment of similarity between marks must be made through the eyes of the average consumer of the relevant goods or services. ${ }^{67}$ The CJEU went on to articulate some characteristics of this 'average consumer'. He or she is regarded as being reasonably well-informed and reasonably observant and circumspect. ${ }^{68}$ However, the average consumer's attention may vary according to what type of goods or services are in issue. ${ }^{69}$ As such, and as is further explained below, the average consumer is said to perceive a mark as a whole, rather than dissecting the mark and focusing on individual elements or details of the mark. ${ }^{70}$

Prior to the European Directive, the most authoritative case in the United Kingdom, Singapore and New Zealand on determining the similarity of marks was Re Pianotist Co's Application. ${ }^{71}$ In assessing whether NEOLA was too similar to PIANOLA to be registered under the provisions of the Patents, Designs and Trade Marks Act 1883, Parker J observed that: ${ }^{72}$

You must take the two words. You must judge of them, both by their look and by their sound. You must consider the goods to which they are to be applied. You must consider the nature and kind of customer who would be likely to buy those goods. In fact, you must consider all the surrounding circumstances ...

In both New Zealand and Singapore, the approach stipulated by the CJEU in SABEL $v$ Puma, and European jurisprudence more generally, has been increasingly influential before the courts and adjudicators. ${ }^{73}$ However, Pianotist still continues to be cited by New Zealand courts ${ }^{74}$ and features in the Practice Guidelines. ${ }^{75}$ Singapore courts have also referred to Pianotist in assessing whether two marks are likely to be confused with each other. ${ }^{76}$ Indeed, in Hai Tong Co (Pte) Ltd v Ventree Singapore Pte Ltd the Court of Appeal described Parker J's comments in Pianotist as a 'pithy and adequate description of the approach to be taken' ${ }^{77}$

'Cola is a word in common use in Canada in naming beverages, it is plain that the distinctive feature in this hyphenated word is the first word "Coca" and not "Cola". "Coca" rather than "Cola" is what would remain in the average memory'.

67. Case C-342/97 Lloyd Schuhfabrik Meyer \& Co GmbH v Klijsen Handel BV [1999] ECR I-03819, ECLI:EU:C:1999:323 at para 25.

68. Ibid at para 26.

69. Ibid at para 26 .

70. Ibid at para 25.

71. Re Pianotist Co's Application (1906) 23 RPC 774.

72. Ibid at 777 .

73. See for example, Intellectual Property Office of New Zealand, 'Practice Guidelines: Relative Grounds - Identical or Similar Trade Marks' <https://www.iponz.govt.nz/about-ip/ trade-marks/practice-guidelines/current/relative-grounds-identical-or-similar-trade-marks/> (last accessed 26 November 2020), which makes reference to SABEL BV v Puma AG, Rudolf Dassler Sport and Canon Kabushiki Kaisha v MGM Inc.

74. Most prominently in New Zealand Breweries (n 27) at 138-9. More recently, see CocaCola v Frucor (n 60) at para 194.

75. Intellectual Property Office of New Zealand, 'Practice Guidelines' (n 73) .

76. Nation Fittings (n 59) at para 99; Polo/Lauren (n 57) at para 27.

77. Hai Tong (n 40) at para 87. 


\subsection{The idea of a mark and imperfect recollection}

Despite the lack of mention of conceptual similarity in Pianotist, English courts have long taken into account the 'idea' of a mark when comparing trade marks. ${ }^{78}$ The Herschell Committee's Report on Trade Marks in 1888 observed: ${ }^{79}$

Two marks when placed side by side may exhibit many and various differences, yet the idea left upon the mind may be the same so that a person acquainted with the mark first registered ... might well be deceived.

The idea or conceptual element of a trade mark is the semantic meaning or content of a trade mark. ${ }^{80}$ A conceptual comparison has also been described as trying to discern 'the feelings and images to be evoked by each mark' ${ }^{81}$ With word marks that are not invented, courts and adjudicators may take judicial notice of the meaning of the words to derive the idea of a trade mark. ${ }^{82}$ Semantic meaning can also be derived from a dictionary. ${ }^{83}$

As is further explained below, in contrast to word marks, with a pictorial mark there is significantly more scope for interpretation when determining the idea of the mark. That said, the idea of a mark will necessarily be derived from its graphic representation. For example, in Société des produits Nestlé SA v OHIM, the senior registered trade mark, shown in Figure 1 was described as 'a red mug on a bed of coffee beans' ${ }^{84}$

In another example, in Twothirds SL v P2M Société par actions simplifiée à associé unique, the senior registered trade mark shown in Figure 2 was described as conveying the concept of a whale. ${ }^{85}$

Finding there is conceptual similarity between two marks is often strengthened by a principle of 'imperfect recollection'. This notion of imperfect recollection was famously summarized by Lord Radcliffe in De Cordova v Vick Chemical Co as follows: ${ }^{86}$

$\ldots$ in most persons the eye is not an accurate recorder of visual detail, and ... marks are remembered rather by general impressions or by some significant detail than by any photographic recollection of the whole.

The CJEU has also said that the average consumer does not have an opportunity to directly compare trade marks and 'must instead rely on the imperfect picture of them he has kept in his mind'. ${ }^{87}$ Further, this notion of imperfect recollection aligns

78. See R. Johnston \& Co v Archibald Orr Ewing \& Co (1882) 7 App Cas 219 (passing off case involving tickets comprising pictures of elephants where the Court had regard to customers who were unable to read and understand the English language).

79. Patent Office Inquiry, Report of the Committee Appointed by the Board of Trade to Inquire into the Duties, Organisation, and Arrangements of the Patent Office (C-5350, 1888), p. viii.

80. Crocodile International (n 25) at para 69.

81. Jamal Abdulnaser Mahmoud Al Mahmid v Global Tobacco Manufacturers (International)

Sdn Bhd [2015] SGHC 42 at para 36.

82. Fhima and Gangjee (n 33) 42.

83. James Mellor QC et al., Kerly's Law of Trade Marks and Trade Names (16th edn, Sweet \& Maxwell, online edition, 2020) at para [23-018].

84. Joined cases T-5/08 to T-7/08 Société des produits Nestlé SA v OHIM [2010] ECR II-01177, ECLI:EU:T:2010:123. Image taken from judgment.

85. Case R 643/2019-4 Twothirds SL v P2M Société par actions simplifiée à associé unique, 20 November 2019 at para 22. Image taken from judgment.

86. De Cordova v Vick Chemical Co (1951) 68 RPC 103 at 106.

87. Lloyd Schuhfabrik (n 67) at para 26. 


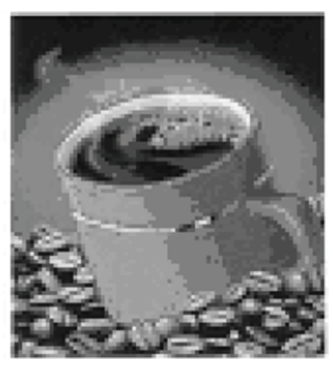

Figure 1 IR 726641

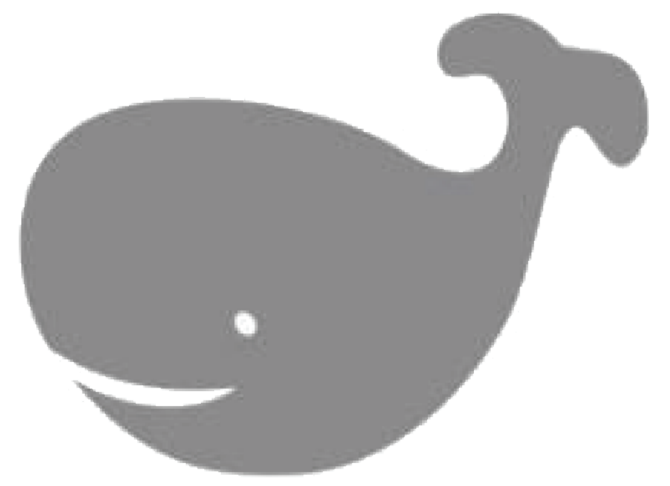

Figure 2 EU Trade Mark No. 15963671

with the principle in European trade mark law (discussed above) that an average consumer normally perceives a mark as a whole, and does not analyse its various details. ${ }^{88}$ 'The overall impression created' by a mark on the average consumer might, in certain circumstances, 'be dominated by one or more of its components' ${ }^{89}$

In some instances, when the courts talk of the importance of the idea of a trade mark they appear simply to be reiterating the principle of imperfect recollection. That is, sometimes the courts seem to be saying that the idea underlying a trade mark might be the dominant element in an average consumer's imperfect recollection of a mark. For example, in Anheuser-Busch Inc v Budweiser Budvar National Corp the New Zealand Court of Appeal said 'the impression or idea conveyed by the marks is important in assessing how they will be recalled' ${ }^{90}$ However, as the next subsection explains, sometimes when courts or adjudicators take into account the idea of a trade mark, this may have a more direct influence on the determination of whether a senior registered trade mark is confusingly similar to a junior mark.

88. Ibid at para 25 .

89. Case C-3/03 P Matratzen Concord v OHIM [2004] ECR 1-3657, ECLI:EU:C:2004:233 at para 32.

90. Anheuser-Busch Inc v Budweiser Budvar National Corp [2003] 1 NZLR 472 at para 75 (emphasis added). See also Pharmazen Ltd v Anagenix IP Ltd [2020] NZCA 306, (2020) 157 IPR 198 at para 47(c): 'the impression or idea conveyed by the marks is important in assessing how they will be recalled; the idea of a mark is more likely to be recalled than its precise details'. 


\subsection{Conceptual similarity within the global approach to similarity}

Generally, in assessing similarity, courts and adjudicators tend to conduct a visual, aural and conceptual comparison in turn, before coming to an overall conclusion as to similarity, bearing in mind the dominant and distinctive elements of the marks. ${ }^{91}$ Adjudicators often express the degree of similarity under each of the elements in terms of whether the similarity is weak, average or strong. ${ }^{92}$ Such an approach envisages that there can be - and often will be - a trade-off in the elements of visual, aural and conceptual similarity. Fhima and Denvir have suggested that visual similarity often has the greatest role to play in decisions before the General Court of the European Union. ${ }^{93}$ Yet, there is no set rule. The CJEU has even indicated that a likelihood of confusion may arise on one element of similarity alone. ${ }^{94}$

Given the nature of the 'global assessment' approach, European case law suggests the weight given to visual, aural and conceptual similarity will be dependent on the nature of the goods or services at issue. ${ }^{95}$ For example, more weight could be expected to be given to visual similarity in cases involving clothing, because clothing is normally purchased by visual inspection. ${ }^{96}$

By contrast, the Singapore Court of Appeal has said that when determining similarity, the comparison is 'mark for mark, without consideration of any external manner' ${ }^{97}$ Thus, the weight to be given to visual, aural or conceptual similarity in light of the nature of the goods or services is taken into account at the likelihood of confusion stage - and not when assessing the similarity of marks. ${ }^{98}$ Under New Zealand law, similarity and likelihood of confusion tend to get rolled-up together. ${ }^{99}$ Following Pianotist, extraneous factors and the circumstances in which the relevant products are sold tend to be taken into account at the similarity of marks stage.

In cases involving the comparison of two word marks adjudicators are able to weigh up similarities between the visual, aural and conceptual elements of the marks in issue. Often clear conceptual differences between marks can point away from a finding of overall similarity. For example, in Hannaford \& Burton Ltd $v$ Polaroid the Privy Council considered that POLAROID conveyed the idea of polarizing light and SOLAVOID conveyed the idea of avoiding the sun. ${ }^{100}$ These ideas were considered to be 'clearly different' and made the likelihood of confusion between the marks unlikely. ${ }^{101}$ In Premier Brands $v$ Typhoon Europe Ltd the different concepts associated with TYPHOON and TY.PHOO obviated the high degree of aural similarity between the marks. ${ }^{102}$ Indeed, in Europe such a situation is said to be an example of

91. See Lionel Bently, Brad Sherman, D Gangjee and P Johnson, Intellectual Property Law (5th edn, Oxford University Press 2018) 1033 and Fhima and Gangjee (n 33) 18.

92. I Fhima and C Denvir, 'An Empirical Analysis of the Likelihood of Confusion Factors in European Trade Mark Law' (2015) 46 IIC 310, 319.

93. Ibid at 328.

94. Lloyd Schuhfabrik (n 67) at para 28 (aural similarity).

95. Fhima and Gangjee (n 33) 19.

96. Jack Wills Ltd v House of Fraser (Stores) Ltd [2014] EWHC 110 (Ch), [2014] FSR 39 at para 85.

97. Staywell (n 34) at para 20. See also Tee Jim Tan SC (n 30) 416.

98. Staywell (n 34) at para 20.

99. See the discussion in Paul Sumpter, Trade Marks in Practice (4th edn, LexisNexis 2018) 98 [para TMA25.10].

100. Hannaford \& Burton Ltd v Polaroid [1976] 2 NZLR 14 at 19.

101. Ibid.

102. Premier Brands UK Ltd v Typhoon Europe Ltd [2000] FSR 767. 
the so-called 'counteraction theory' - where conceptual differences counteract visual and aural similarities. ${ }^{103}$ The most famous example of this is arguably Ruiz-Picasso v OHIM, where the clear meaning of PICASSO counteracted the mark's visual and aural similarities with PICARO. ${ }^{104}$

Conversely, there is a general reluctance for conceptual similarities, alone, to lead to a finding of overall similarity between two word marks. For example, in considering the similarity between WILD TURKEY and WILD GEESE, the New Zealand Intellectual Property Office (IPONZ) found that despite the marks referring to wild birds, the dominant and distinctive elements of the respective marks were the words TURKEY and GEESE, which were visually and aurally 'significantly different' ${ }^{105}$ The High Court disagreed, ${ }^{106}$ but the Court of Appeal upheld IPONZ's decision. ${ }^{107}$ The Court of Appeal observed that weight should be given to the aural and visual differences between TURKEY and GEESE, and that the concept of a large game bird 'was not a controlling consideration'. ${ }^{108}$

Similarly, in the Australian case of Cooper Engineering Co Pty Ltd v Sigmund Pumps Ltd, the owner of RAIN KING was not able to prevent the registration of RAINMASTER. ${ }^{109}$ The High Court identified that the marks were visually and aurally distinct. ${ }^{110}$ The High Court went on to explain the rationale for not overweighting conceptual similarity: 111

To refuse an application for registration on this ground would be to give the proprietor of a registered trademark a complete monopoly of all words conveying the same idea as his trademark. The fact that two marks convey the same idea is not sufficient in itself to create a deceptive resemblance between them, although this fact could be taken into account in deciding whether two marks which really looked alike or sounded alike were likely to deceive.

When the marks in issue involve a senior word mark and a junior pictorial mark or a junior combination mark (i.e. comprising images and text), conceptual similarity may also result in a finding of overall confusing similarity between the marks. For example, a word such as SEAHORSE may convey the same idea as a graphical depiction of the species of small marine fish. ${ }^{112}$ It does not automatically follow, though, that a junior pictorial mark which represents a meaning associated with a senior word mark will result in a finding of similarity between the marks. Much will depend on the specificity of the idea or meaning that the senior word mark in issue brings to mind, and whether that is replicated in (or would be triggered by)

103. Fhima and Gangjee (n 33) 46-8.

104. C-361/04 P - Ruiz-Picasso v OHIM [2006] ECR I-00643, ECLI:EU:C:2006:25 at para 20.

105. Stichting Lodestar v Austin Nichols \& Co [2004] NZIPOTM 11.

106. Austin, Nichols \& Co Inc v Stichting Lodestar (2005) TCLR 265. The High Court placed more weight on the idea of the marks, and found at para 31 that the 'idea similarity' of a wild hunted game bird would lead to confusion.

107. Stichting Lodestar v Austin, Nichols \& Co Inc [2007] NZCA 61.

108. Ibid at para 31. The Supreme Court dismissed an appeal in Austin, Nichols \& Co Inc v Stichting Lodestar [2007] NZSC 103, [2008] 2 NZLR 141.

109. Cooper Engineering Co Pty Ltd v Sigmund Pumps Ltd (1952) 86 CLR 536.

110. Ibid at 538 .

111. Ibid at 539 .

112. Cf. University of Northumbria at Newcastle v Seahorse Holdings Ltd, Trade Mark Registry, O/046/03. 
a particular image. ${ }^{113}$ For example, in Hearst Holdings Inc $v$ AVELA Birss $\mathrm{J}$ found that the word mark BETTY BOOP had been infringed by the importation and sale of products bearing an image of the Betty Boop character. ${ }^{114}$ There was a strong association between the image and the words, and Birss $J$ found that the image of the character would inevitably trigger the words. ${ }^{115}$

In the course of his judgment in Hearst Holdings Birss $\mathrm{J}$ distinguished the earlier case of La Chemise Lacoste SA v Baker Street Clothing Ltd. ${ }^{116}$ In that case Baker Street Clothing Ltd had applied to register the word ALLIGATOR. Lacoste opposed registration relying on a pictorial mark comprising of an image of a crocodile. Geoffrey Hobbs QC found that the marks were not 'linkable by any conceptual similarity of which the relevant average consumer was likely to take cognisance', ${ }^{117}$ and that it had not been sufficiently established that there would be sufficient similarity to lead to a likelihood of confusion. ${ }^{118} \mathrm{He}$ observed that it was 'a matter for careful consideration whether a particular word has the power to trigger perceptions and recollections of a particular image'. ${ }^{119}$ In his view, there was insufficient evidence to show that the word ALLIGATOR would trigger an image of Lacoste's trade mark with 'spontaneity and specificity'. 120

\subsection{The challenge of pictorial marks}

Where the marks in issue are pictorial marks there may be a more significant challenge for adjudicators assessing similarity and an even greater risk of one trader obtaining a monopoly over an idea. Pictorial trade marks provide less scope for adjudicators to balance visual, aural and conceptual similarities or differences. In contrast to word marks, pictorial marks do not have an obvious aural element. As a result, weight tends to be divided solely between visual and conceptual elements.

Further, the visual and conceptual elements of a pictorial mark will inevitably overlap as the visual impact of a pictorial trade mark will necessarily reflect the concept or subject matter of the mark. ${ }^{121}$ Overweighting conceptual similarity might result in an adjudicator extending the scope of protection of a senior registered trade mark to encompass an idea or concept itself. Quite apart from the competition and freedom of expression concerns such an extension would entail, trade mark law does not, and should not, award one trader with exclusivity over an idea. As Geoffrey Hobbs

113. See Hearst Holdings Inc v AVELA [2014] EWHC 439 (Ch), [2014] FSR 36 at para 154, referring to the word mark examples MONA LISA, EIFFEL TOWER and STARS AND STRIPES, which were first referred to in La Chemise Lacoste SA v Baker Street Clothing Ltd [2011] RPC 5 at para 55 [Baker Street].

114. Hearst Holdings Inc v AVELA (n 113). Further in Case T-424/10 Dosenbach-Ochsner AG Schuhe und Sport v OHIM, ECLI:EU:T:2012:58 [Dosenbach-Ochsner] at para 51 the General Court found a registration for the word 'elefanten' (meaning elephant in German) was conceptually identical to the junior mark referenced by $\mathrm{n} 139$ and the accompanying text.

115. Hearst Holdings Inc v AVELA (n 113) at para 156.

116. Baker Street (n 113).

117. Ibid, at para 51. At best, Hobbs QC found, at para 56, that there was only a 'loose, general and non-confusing association between them'.

118. Ibid at para 56.

119. Ibid at para 49.

120. Ibid at para 56.

121. Jeremy Philips, Trade Mark Law: A Practical Anatomy (Oxford University Press 2003) 321. 
QC observed in La Chemise Lacoste SA v Baker Street Clothing Ltd, the owner of a registered trade mark should not be entitled to object to any marks with a similar concept or idea. ${ }^{122}$ Referring to Dyson Ltd v Registrar of Trade Marks, he identified that 'a concept is not a sign capable of being protected by registration as a trade mark'. ${ }^{123}$

To obviate the risk of a senior pictorial registered trade mark owner obtaining a monopoly over an idea or concept, care needs to be exercised in assessing conceptual similarity. The next section explains how and why adjudicators could exercise such care in giving appropriate weight to conceptual similarity when assessing the overall similarity between a senior registered trade mark and a junior mark.

\section{HOW AND WHY CARE SHOULD BE EXERCISED WHEN ASSESSING CONCEPTUAL SIMILARITY IN CASES INVOLVING PICTORIAL MARKS}

\subsection{Identifying the idea of a mark}

One of the first issues in determining the appropriate weight to be given to conceptual similarity is identifying precisely what idea is conveyed by the senior registered trade mark and the junior mark or sign. Indeed, identifying what information a sign conveys to consumers is a perennial problem for trade mark law. All signs are open to interpretation. The meaning derived by a person perceiving a sign will depend on the context and the relationship a sign has with other signs within a particular signification 'system' or 'code', such as the English alphabet system or the letter conventions of algebra. ${ }^{124}$ However, in trade mark law, the diversity of meanings associated with word marks are, to an extent, hedged in by the constraints of language and the emphasis adjudicators give to the 'ordinary meaning' of words. By contrast, pictorial marks are less constrained by language, and the idea of a pictorial mark is open to far more interpretations. As the idiom holds: a picture is worth a thousand words.

The Singaporean case of Rovio Entertainment Ltd v Kimanis Food Industries Sdn $B h d$ provides a good illustration of the potential impreciseness involved in identifying the idea of a pictorial mark. ${ }^{125}$ Rovio Entertainment Ltd (Rovio) owned a registered word mark for ANGRY BIRDS and the pictorial mark set out in Figure 3.

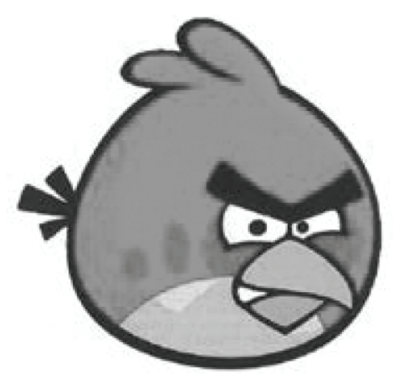

Figure 3 Trade Mark Registration No. T1111886Z

122. Baker Street (n 113) at para 47.

123. Case C-321/03 Dyson Ltd v Registrar of Trade Marks [2007] ECR I-00687, ECLI:EU: C:2007:51 at paras 27 to 40 .

124. Marcel Danesi, Brands (Routledge, London 2006) 25-9.

125. Rovio (n 19). 


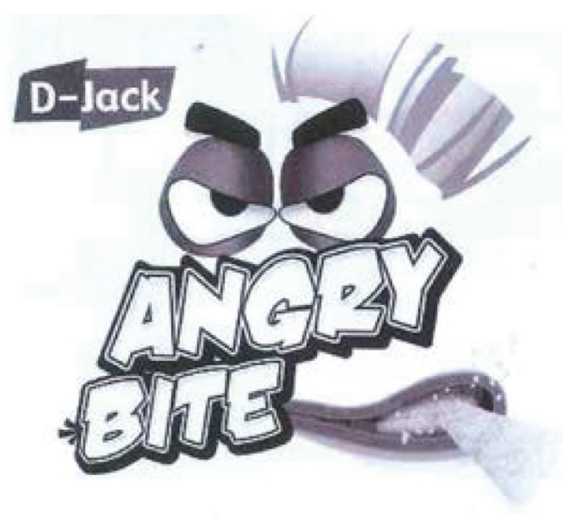

Figure 4 Trade Mark Registration No. T1111886Z

Kimanis Food Industries Sdn Bhd (Kimanis) applied to register the mark set out in Figure 4. ${ }^{126}$

Rovio argued that Kimanis' application conveyed the idea of a bird. It produced evidence that the Malaysian Trade Marks Registry had described the mark as a 'bird'. The Singapore Trade Mark Registry found that Kimanis' application conveyed the idea of some kind of creature biting angrily. ${ }^{127}$ The High Court agreed that there was conceptual dissimilarity, finding that Kimanis' application did not convey 'the impression or idea of a bird'. ${ }^{28}$

Similar ambiguities as to the idea of a mark can be illustrated by American Home Products Corp v Knoll Aktiengesellschaft. ${ }^{129}$ The opponent claimed its mark, shown in Figure 5, depicted a person walking or running. ${ }^{130}$ The applicant, though, adduced evidence from one of the opponent's employees who described the opponent's mark as 'a little red apple with a green man inside'.

Visual similarities and differences between marks can often be readily objectively identified and characterized. By contrast, as the illustrations above demonstrate, identifying the idea of a pictorial mark can be a far more subjective and ambiguous exercise, compounded by the propensity for consumers and adjudicators to draw multiple and potentially different ideas from a mark. ${ }^{131}$

The ambiguity associated with identifying the idea of a pictorial mark is enhanced by the fact that ideas or concepts underlying a pictorial mark can be identified at different levels of abstraction. For example, in SABEL v Puma, SABEL BV applied to register the mark in Figure 6 on the left. ${ }^{132}$ This mark was judged to represent a

126. Both images taken from the judgment, and it is acknowledged that Kimanis' mark contains text and is therefore not solely a pictorial mark.

127. Rovio Entertainment Ltd v Kimanis Food Industries Sdn Bhd [2014] SGIPOS 10 at paras $65-6$.

128. Rovio (n 19) at para 88.

129. American Home Products Corp v Knoll Aktiengesellschaft (Trade Mark Opposition Decision (0/354/01), 15 August 2001). Upheld on appeal, American Home Products Corp $v$ Knoll Aktiengesellschaft [2002] EWHC 828 (Ch).

130. Image taken from the Trade Mark Opposition Decision (0/354/01), 15 August 2001.

131. As noted by the New Zealand Supreme Court in Crocodile International (n 25) at para 63. 132. SABEL v Puma (n 38). Images taken from the judgment. 


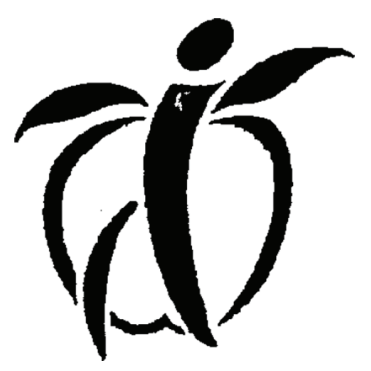

Figure 5 IR 698501
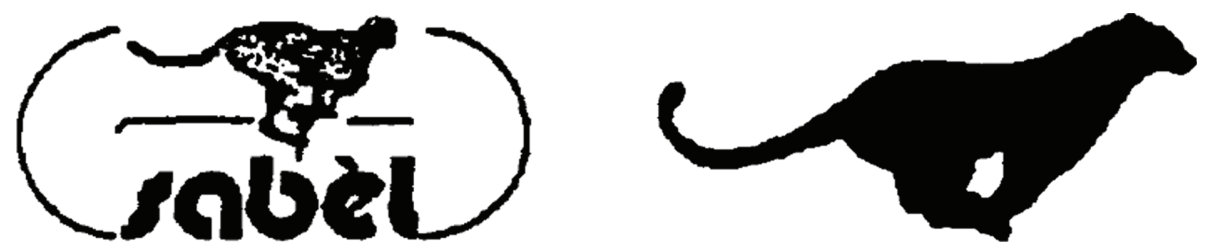

Figure 6 IR 540894 (left) and German Trade Mark Registration No. 1106066 (right)

cheetah 'bounding'. ${ }^{133}$ Puma Aktiengesellschaft Rudolf Dassler Sport (Puma) owned the registered trade mark on the right, and opposed the application. Puma's trade mark was judged to represent a 'bounding puma'. 134

However, the marks in SABEL v Puma could have been identified at a higher level of abstraction, such as a 'bounding feline'. The higher the level of abstraction that one uses to identify an idea, the broader the idea will be, and the greater the prospect of semantic similarity with another mark.

The impact of the degree of abstraction on the evaluation of conceptual similarity can be illustrated by Jack Wills Ltd $v$ House of Fraser (Stores) Ltd. ${ }^{135}$ Jack Wills was the owner of the registered trade mark on the left in Figure 7. House of Fraser began using the trade mark on the right. ${ }^{136}$ Jack Wills commenced trade mark infringement proceedings.

Arnold J identified the idea of the marks at a relatively low level of abstraction, and concluded that there was a 'high degree of conceptual similarity' between the marks. ${ }^{137}$ Arnold J observed that there were conceptual differences between the marks, such as Jack Wills' mark being a pheasant, and House of Fraser's mark being a pigeon. However, Arnold J observed: ${ }^{138}$

In both cases the concept is not merely a silhouette of an anthropomorphised bird, but more specifically a silhouette of a bird with accoutrements suggestive of an English gentleman, in particular a top hat.

By contrast, in the European case of Dosenbach-Ochsner v OHIM it was recognized that, visually, the contested junior mark in Figure 8 on the right had a 'rather child-like

133. SABEL v Puma (n 38), Opinion of AG Jacobs (ECLI:EU:C:1997:221), at para 3.

134. Ibid at para 4.

135. Jack Wills (n 96).

136. Both images taken from the judgment.

137. Jack Wills (n 96) at paras 94-5.

138. Ibid at para 94. 

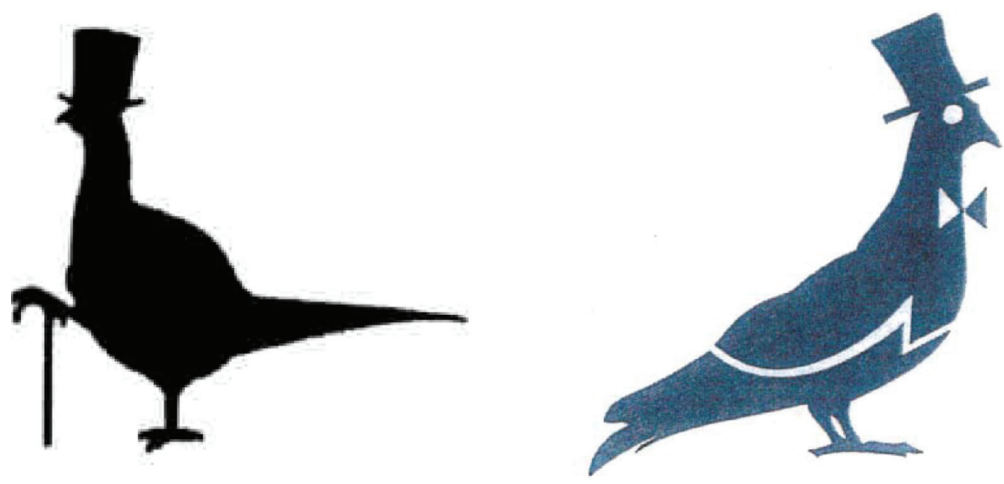

Figure 7 UK Trade Mark No. 2449189/IR 0971102 (left) and House of Fraser's Pigeon Logo (right)
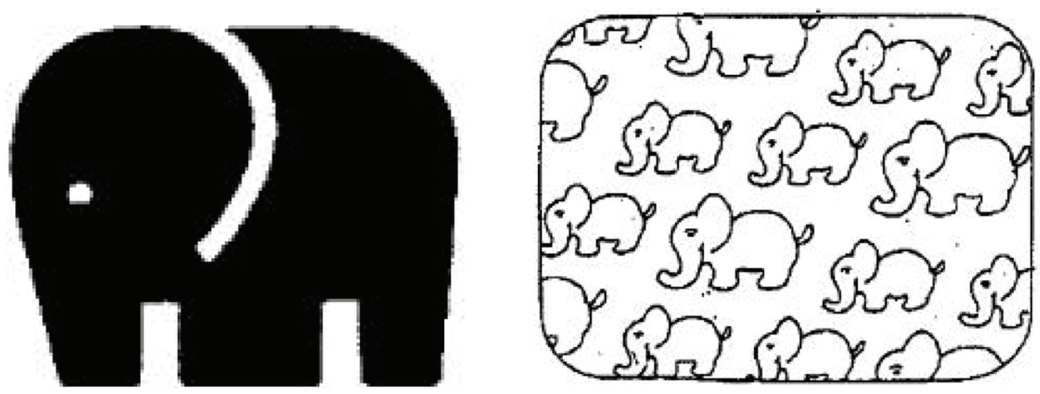

Figure 8 IR 71509 and German Trade Mark Registration No. 30082400 (left) and EU Trade Mark No. 4279295 (right)

nature' compared to the senior mark's 'abstract and clear-cut design' (on the left). ${ }^{139}$ However, the idea of the marks was identified at a high level of abstraction, and both were described as conveying the concept of an elephant. ${ }^{140}$

Despite the principle of imperfect recollection, it is submitted that courts and adjudicators should be wary of identifying the idea of a trade mark at such a high level of abstraction, lest this lead to an overweighting of conceptual similarity, ignoring visual differences and effectively giving a trader a monopoly over a particular idea or motif. For instance, if the idea of an image of a member of a crocodilian species is identified as simply a 'crocodile' this risks extending protection to encompass all images of crocodiles, caimans, alligators and gharials. Similarly, if the image of a member of the family of bovine animals is identified as 'bovine', this risks extending protection to encompass water buffalo, cattle and bison. It also may encompass all types of representations of such animals - swimming, basking, walking, or leaping - and all styles of representation of such animals - such as cartoon or photographic. Consider, for example, the Crocs logo, set out in Figure 9. ${ }^{141}$

139. Dosenbach-Ochsner (n 114) at para 33. Images taken from the judgment. 140. Ibid at para 52.

141. Image derived from the Trade Marks Register on 29 January 2021. 


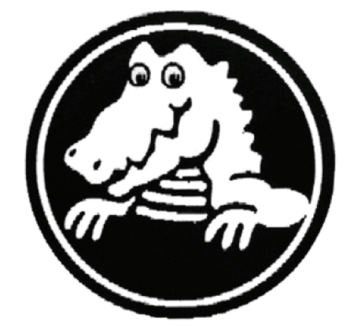

Figure 9 United Kingdom Trade Mark Registration No. 244338

At a low level of abstraction, it may be construed as conveying the idea of an upright, front-facing cartoon crocodile. At a high - and arguably an undesirable level of abstraction it could be said to simply convey the idea of a crocodile.

\subsection{The distinctiveness of an idea}

Another way to avoid overweighting conceptual similarity is to pay appropriate regard to the distinctiveness (in a non-technical sense) of the ideas of marks when assessing conceptual similarity. That is, to have regard to the extent to which the idea is unusual in the sense of standing out. This seems to have been a relevant consideration in Jack Wills. Although there was evidence of other bird logos in use in the clothing industry, none were a pheasant or pigeon. Further, only one was standing (as opposed to being in flight) and none had 'human accessories'. ${ }^{142}$ What 'stood out' conceptually with Jack Wills' trade mark was its 'anthropomorphic aspect' and that the image of the bird was 'equipped with accessories associated with an English gentleman'. ${ }^{143}$

The relevance of the non-technical distinctiveness of the alleged shared concept was also apparent in the Advocate General's opinion in SABEL v Puma. The Advocate General considered it possible that there could be a likelihood of confusion between marks based on conceptual similarity alone if two pictorial marks conveyed the same 'unusual invented image' or an 'unusual combination of natural images'. ${ }^{144}$ The Advocate General used the hypothetical example of a 'puma playing a violin'. ${ }^{145}$ The CJEU echoed the Advocate General's opinion observing that where the senior mark was not well-known and the image had 'little imaginative content', conceptual similarity arising from the junior mark using an image with 'analogous semantic content' was not sufficient to give rise to a likelihood of confusion. ${ }^{146}$

As the CJEU intimated in SABEL v Puma, the technical distinctiveness of the senior mark may impact on how much the idea stands out. That is, distinctiveness in the sense of the capacity of the senior mark to distinguish goods and services - as opposed to the mark being descriptive or laudatory of the goods and services. For example, in Infamous Nut Co Ltd's Trade Marks, the applicant had applied to register a series of image marks comprising a monkey eating a 'monkey nut' for nut products in class 29 and class 31, as set out in Figure 10. ${ }^{147}$

142. Jack Wills (n 96) at para 50.

143. Ibid at para 87.

144. SABEL v Puma (n 38), Opinion of AG Jacobs (ECLI:EU:C:1997:221) at para 61.

145. Ibid at para 61.

146. SABEL v Puma (n 38) at paras 24-5.

147. Infamous Nut Co Ltd's Trade Marks [2003] RPC 7 (images taken from the judgment). 

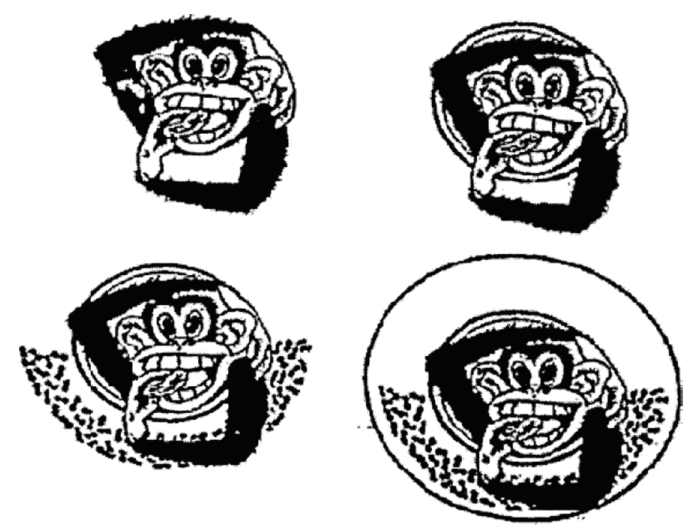

Figure 10 United Kingdom Trade Mark Application No. 2070392

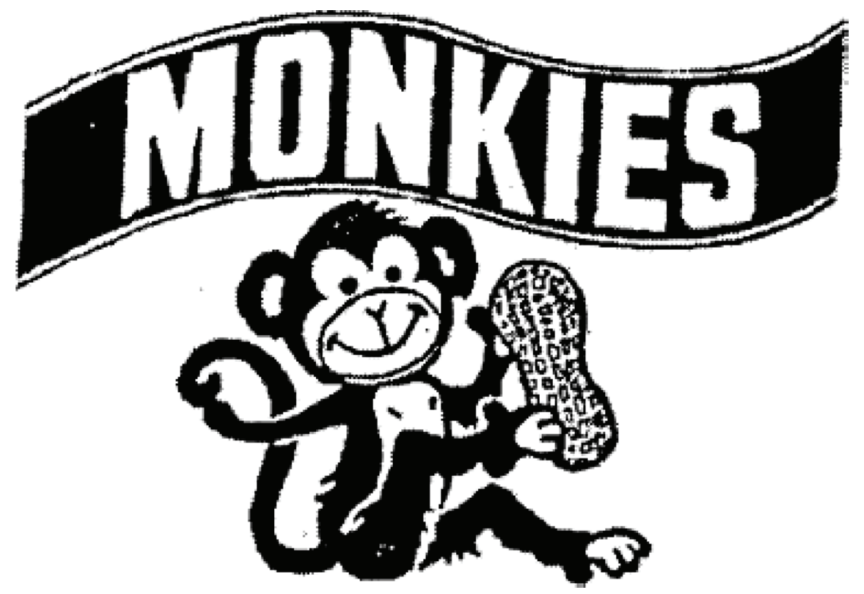

Figure 11 United Kingdom Trade Mark Registration No. 966175

This application was opposed. The opponent owned earlier trade marks, one of which was of an image of a monkey holding a peanut, as shown in Figure 11.

The Appointed Person, Professor Ruth Annand, observed that the concept of monkeys and nuts are closely linked in the minds of the public. ${ }^{148}$ Citing the reference to 'imaginative content' in SABEL v Puma, and even having regard to imperfect recollection, she found the use of the applicant's marks was unlikely to give rise to a likelihood of confusion. ${ }^{149}$

Conversely, if the pictorial mark is strongly technically distinctive in relation to the goods or services, there may be a higher prospect that conceptual similarity could give rise to a likelihood of confusion. For example, in Glenn Elliott v Heineken Asia Pacific Pte Ltd the Assistant Commissioner at IPONZ refused to register the mark on the left in Figure 12 in relation to 'pre-mixed alcoholic beverages'. The opponent relied upon a 

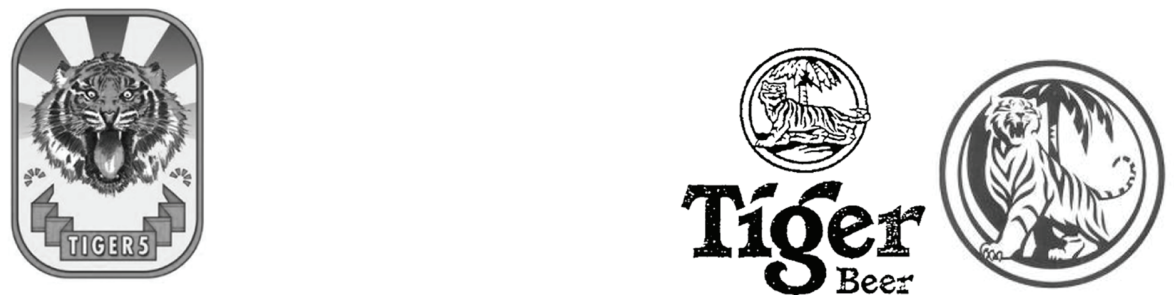

Figure 12 New Zealand Trade Mark Application No. 850544 (left) and New Zealand Trade Mark Registration Nos. 294483 and 742712 (right)

number of senior registered trade marks, including the marks on the right in Figure 12 covering beer. ${ }^{150}$

Tigers and alcoholic beverages are arguably not inherently linked in the same way as monkeys and nuts.

However, the apparent distinctiveness of a pictorial mark should not be pushed too far where the image is drawn from nature and closely follows a natural or innate representation. In such a case, the image will be imbued with little additional imaginative content, and what enables the image to 'stand out from the crowd' has little to do with a particular trader. To take a copyright example, in Beckmann v Mayceys Confectionery Ltd, Mayceys was the owner of copyright in an artistic work of a crocodile that was used in the manufacture of confectionery. ${ }^{151}$ The Court of Appeal pointedly observed: ${ }^{152}$

There can be little doubt that the original designer of the crocodile had a flair for the distinctive. But that was not Mr Stacey of Mayceys.

\subsection{Avoiding putting too much emphasis on the central message of a trade mark}

A further way to steer away from putting too much weight on conceptual similarity is to avoid treating the idea or concept of a senior registered trade mark as its 'essential feature', and then focusing on whether the junior mark has taken this 'essential feature'. The notion of a trade mark's essential feature can be traced to Saville Perfumery Ltd $v$ June Perfect Ltd, ${ }^{153}$ and de Cordova $v$ Vick Chemicals, where the Privy Council said a mark could be infringed if a defendant 'uses one or more of its essential features'. ${ }^{154}$ Drawing on de Cordova $v$ Vick Chemicals, in New Zealand Breweries Ltd v Heineken's Bier Browerij Maatschappij NV, North P said: ${ }^{155}$

But while it is true that it is necessary to have regard to 'the totality' of the proposed trade mark, yet often enough the real risk of confusion may lie in some common feature in the two labels which is liable to linger in the minds of persons requiring a particular kind of goods.

150. Glenn Elliott v Heineken Asia Pacific Pte Ltd [2014] NZIPOTM 18. Images taken from the decision.

151. Beckmann v Mayceys Confectionery Ltd (1995) 33 IPR 543.

152. Ibid at 546.

153. Saville Perfumery Ltd v June Perfect Ltd (1941) 58 RPC 147.

154. de Cordova (n 86) at 105-6.

155. New Zealand Breweries (n 27) at 134. 
This statement echoes the CJEU's guidance that the overall impression of a complex trade mark may be 'dominated by one or more of its components'. ${ }^{156}$ It also reflects the principle of imperfect recollection. ${ }^{157}$ However, it is submitted that conceptual similarity may be inadvertently overweighted where the shared idea of the marks being compared is considered to be an essential feature or the distinctive and dominant element.

The potential impact of treating the idea of a mark as its essential feature can be illustrated in the long-running saga between Crocodile International Pte Ltd (CIPL) and Lacoste before the New Zealand courts. ${ }^{158}$ CIPL made an application to revoke Lacoste's registration no. 70068 for non-use. The issue for the court was whether Lacoste's use of the marks shown in Figure 13, and the word CROCODILE, should count as use of registration no. 70068.

Under the 2002 Act, use for the purposes of genuine use includes 'use in a form differing in elements that do not alter the distinctive character of the trade mark in the form in which it was registered'. ${ }^{159}$ The High Court had held that the differences between the marks Lacoste had used and registration no. 70068 were insignificant, and therefore Lacoste had put registration no. 70068 to genuine use. ${ }^{160}$ On appeal, the Court of Appeal agreed. The Court noted that there were visual differences between registration no. 70068 and the Lacoste marks. ${ }^{161}$ However, the Court of Appeal found that in terms of an 'overall impression' the distinctive character of registration no. 70068 was 'dominated by the image of the crocodile'. ${ }^{162}$ The Court of Appeal observed: 'the crocodile is the central idea and message ... it is all about the crocodile'. ${ }^{163}$ The same central message was in the marks used by Lacoste, and so the distinctive character of the trade mark as registered was not altered.

The Supreme Court, though, disagreed with the approach taken by the Court of Appeal. The Supreme Court suggested that concentrating on the central message of a mark 'risks ignoring or downplaying potentially significant visual differences between trade marks'. ${ }^{164}$ It warned that focusing on the central message of a trade mark could extend the 'penumbra' of protection given to a registered trade mark that protects against others using (or seeking to register) similar trade marks. ${ }^{165}$ This extension could also give a registrant a 'significant first-mover advantage' by gaining exclusivity over the concept of a particular animal. ${ }^{166}$

Although Crocodile International PTE Ltd v Lacoste was not about a likelihood of confusion it provides a useful illustration of the dangers of overweighting conceptual

156. Case C-3/03 Matrazen Concord GmbH v OHIM [2004] ECR I-03657, ECLI:EU: C:2004:233, at para 32. Cf. Case C-120/04 Medion AG v Thomson Sales Germany \& Austria $\mathrm{GmbH}$ [2005] ECR I-08551 ECLI:EU:C:2005:594.

157. Hai Tong (n 40) at para $40(\mathrm{~d})$.

158. See Crocodile International (n 25).

159. Trade Marks Act 2002 (NZ), s 7(1)(a).

160. Lacoste v Crocodile International Pte Ltd [2014] NZHC 2349, overturning the decision of the Assistant Commissioner in Lacoste v Crocodile International Pte Ltd [2014] NZIPOTM who found that Lacoste had not put trade mark registration no. 70068 to genuine use.

161. Crocodile International Pte Ltd v Lacoste [2016] NZCA 111, (2016) 14 TCLR 333 at para 19.

162. Ibid at para 20.

163. Ibid at para 20.

164. Crocodile International (n 25) at para 61.

165. Ibid at para 62.

166. Ibid: 'it could potentially allow a trader to register trade marks for multiple representations of a particular animal, use only one image, and still retain protection over all the trade marks'. 

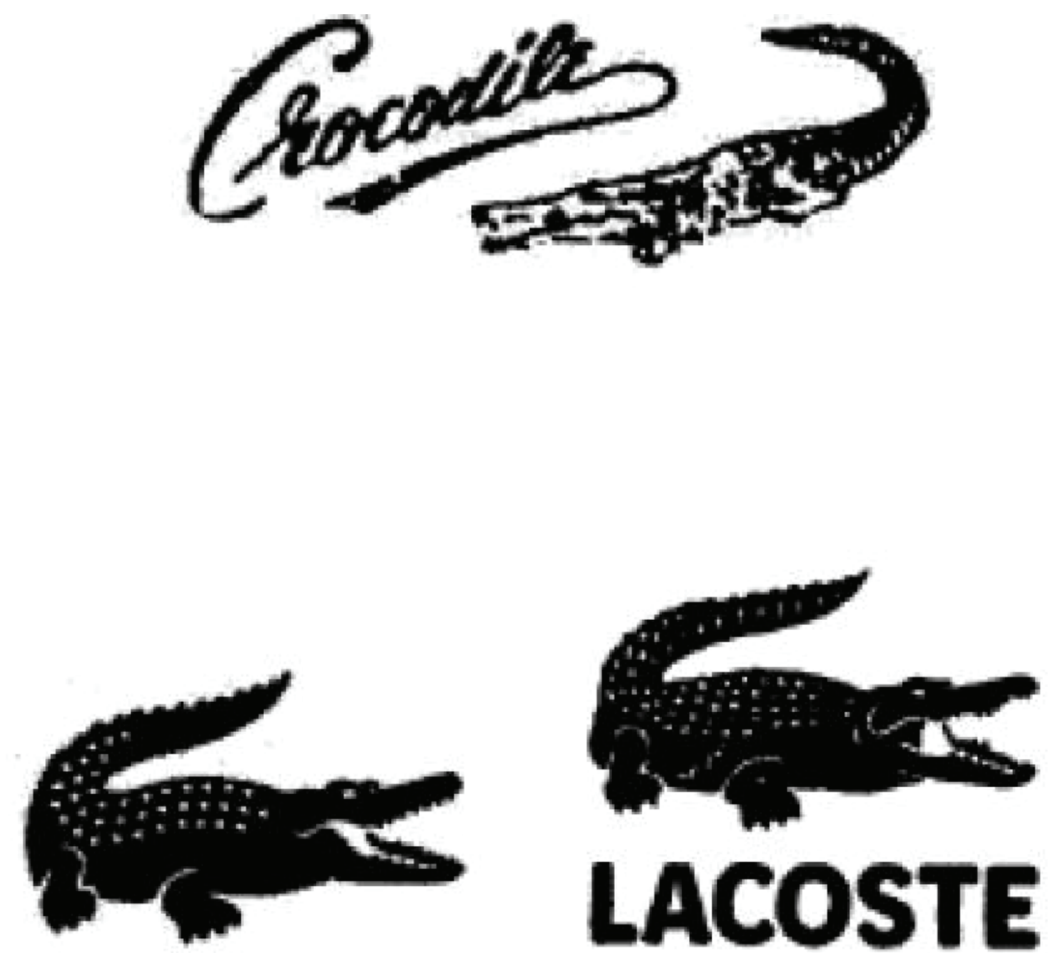

Figure 13 New Zealand Trade Mark Registration No. 70068 (above) and Lacoste's Device and Combined Device and Word marks as used (below)

similarity. Images of the same subject matter may be expressed differently, yet convey the same idea. In Western art, for example, the formal aspects of an artwork includes colour, tone, line, shape, form, space and texture. As a whole, these formal aspects can be associated with 'artistic style', a term which typically refers to the manner of execution of an artwork. ${ }^{167}$ Addressing pictorial images more generally, it has been suggested that an image can fit a style ranging across a spectrum. At one end, an image may be 'photographic' or 'representational' - conforming to the subject matter closely; 'expressionistic' - which leans towards abstraction; and 'cartoon' - which is an animated caricature of the subject. ${ }^{168}$ Therefore, images of the same subject matter may embody the concept of a horse, yet have completely different visual styles, as per the example in Figure 14 from Scatizza v OHIM. ${ }^{169}$

167. See Jean C Rush and Darrell L Sabers, 'The Perception of Artistic Style' (1981) 23 Studies in Art Education 24.

168. See Rune Pettersson, Visual Information (2nd edn, Educational Technology Publications 1993 ) 87, drawing on M Sloan, Picture Preferences of Elementary School Children and Teachers (Ann Arbor, MI, University Microfilms 1971).

169. Case T-238/10 - Scatizza v OHIM - Jacinto (Horse Couture) [2011] ECR II-00372, ECLI: EU:T:2011:613. Images taken from the judgment. It is recognized that the marks are not purely pictorial as they also include text. 

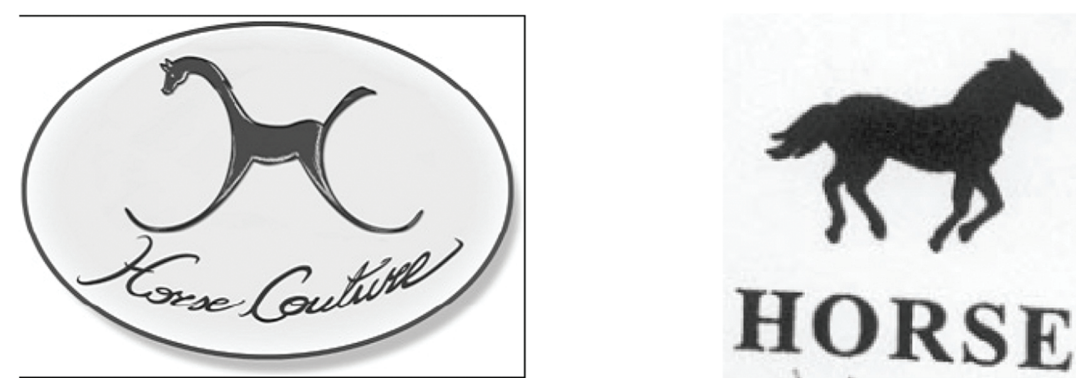

Figure 14 EU Trade Mark Application No. 6030399 (left) and Portuguese Trade Mark Registration No. 379879 (right)

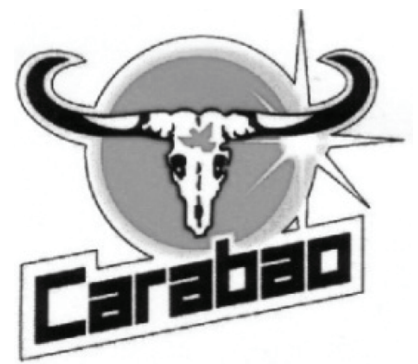

Figure 15 New Zealand Trade Mark Application No. 704080

Treating the idea of a pictorial mark as the central message runs the risk of ignoring visual differences and dissimilarities in style between marks, and losing sight of the fact that trade mark law does not seek to protect concepts or ideas. For example, in Carabao Tawandang Co Ltd v Red Bull GmBH at issue was the registrability of the mark shown in Figure 15. ${ }^{170}$

This trade mark application was opposed by Red Bull $\mathrm{GmbH}$, relying on various marks, including a pictorial mark of two bulls charging each other, as set out in Figure 16.

The Assistant Commissioner at IPONZ observed that although there were significant visual differences, the marks shared the same main idea of a male bovine or bull. ${ }^{171}$ On appeal in the High Court, Clifford J agreed, observing: ${ }^{172}$

I am left with the overall impression that the central concept of the two marks is that of a horned cattle beast or bull, in association with the colour red.

Possibly reflecting the prominent visual differences between Red Bull's marks and Carabao Tawandang Co Ltd's mark, in Australia the same application proceeded to registration, ${ }^{173}$

170. Carabao Tawandang Co Ltd v Red Bull GmbH HC Wellington CIV-2005-485-1975, 31 August 2006. Image taken from Carabao Tawandang Co Ltd v Red Bull GmbH [2005] NZIPOTM 25. It is recognized that this mark is not a purely pictorial mark as it includes text. 171. Carabao Tawandang Co Ltd v Red Bull GmbH [2005] NZIPOTM 25.

172. Carabao Tawandang (n 170) at para 54.

173. See Australian Trade Mark Registration no. 977558. 


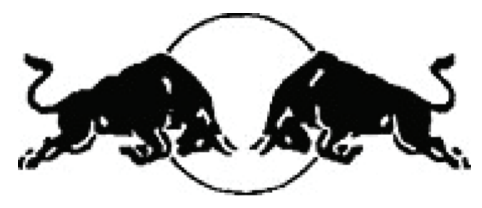

Figure 16 New Zealand Trade Mark Registration No. 309554

and a refiled New Zealand application has also proceeded to registration. ${ }^{174}$ Further, there is some evidence that IPONZ practice is now more circumspect when weighing up alleged conceptual similarity between trade marks. ${ }^{175}$

\subsection{The role of the Register}

A final reason not to overweight conceptual similarity is the role of the Register. For a property right to function as a right in rem, which imposes duties on others not to use or access a thing, resource or activity, there must be a mechanism that conveys information to people as to what behaviour is constrained. ${ }^{176} \mathrm{In}$ real property law, the boundaries of land are surveyed, marked and recorded on a map. This survey carries legal weight, forming the boundaries of an owner's legal title to a parcel of land. ${ }^{177}$ The recording of real property titles on a public register further helps reduce the information cost to the public in determining what property exists and the boundary of a parcel of land. ${ }^{178}$

In trade mark law, the Register is intended to similarly determine the scope of what is protected by a registered trade mark. Indeed, in Sieckmann v German Patent Office the CJEU suggested that the graphic representation of a mark recorded on the Register frames the boundaries of the property rights in a registered trade mark. The CJEU explained that the representation defines 'the mark itself in order to determine the precise subject of the protection afforded by the registered mark to its proprietor'. ${ }^{179}$

It is beneficial for other traders and members of the public that the Register helps identify the scope of the property rights in a registered trade mark. It provides some

174. See New Zealand Trade Mark Registration no. 791278.

175. See, for example, the range of cases involving Monster Energy Co, including Nutrition Fit 2004, Ltd v Monster Energy Co [2018] NZIPOTM 19 at para 47 ('the conceptual similarity between the respective marks is minimal and ultimately insignificant'); Paramount Pictures Corp v Monster Energy Co [2018] NZIPOTM 21 at para 45 ('conceptual similarity between the respective marks is not such as to be determinative in the present case') and NBA Properties, Inc v Monster Energy Co [2019] NZIPOTM 23 at para 67 ('low degree of conceptual similarity').

176. Thomas W Merrill and Henry E Smith, 'What Happened to Property in Law and Economics?' (2001) 111 Yale Law Journal 357, 387.

177. J Bessen and MJ Meurer, Patent Failure: How Judges, Bureaucrats, and Lawyers Put Innovators at Risk (Princeton University Press 2008) 10 and 53.

178. Merrill and Smith (n 176) 394-5.

179. Case C-273/00 Sieckmann v German Patent Office [2002] ECR I-11737, ECLI:EU: C:2002:748, at para 48. See also Bently, Sherman, Gangjee and Johnson (n 91) 1105, 'it is the register that defines the property, via the graphic representation, which delineates the mark'. They qualify this statement by saying it is a 'starting point'. 
degree of predictability that can help guide behaviour. As the Singapore High Court observed in Rovio Entertainment Ltd v Kimanis Food Industries Sdn Bhd: ${ }^{180}$

... members of the public whose duty it is not to infringe registered trade marks are entitled to know with objective certainty which trade marks (and what they comprise) are protected by registration.

As Burrell and Handler have observed, what is on the Register is more a 'signpost' to the scope of the property rights in a registered trade mark, than a 'fence post'. ${ }^{181}$ This is because, as explained above, one category of infringement requires a likelihood of confusion, which cannot be determined a priori and may require a sophisticated understanding of trade mark law. Nevertheless, it remains the case that when enforcing its registered trade mark an owner is restricted to the precise form of the trade mark as it features on the Register. ${ }^{182}$ Subject to a point developed in section 5.1 below, when determining infringement, the comparison is said to be between the trade mark as represented on the Register against the actual use or threatened use of a sign by the defendant. ${ }^{183}$ This means that the registered trade mark owner cannot try and extend the scope of its property rights conferred by a trade mark registration by relying on other signs it has used in the marketplace. ${ }^{184}$ As the Court of Appeal said in L'Oréal SA v Bellure NV: $:^{185}$

There is simply no warrant in the Directive for taking more than the registered mark into account. The global appreciation test does not amount to the proposition that once a registered mark is used in marketing, anything, extraneous to the mark used in marketing, comes in too - as though it formed part of the registered mark.

The Vienna Classification System establishes a hierarchical, numbered classification for trade marks that contain figurative elements. ${ }^{186}$ This system proceeds from the general to the specific, and includes auxiliary sections. For example, Category 3 of the 'Vienna Descriptors' is 'Animals'. Section 3.1 is 'Quadrupeds (Series 1)'; Section 3.1.1 is 'Lions' and Auxiliary Section 3.1.2 is 'Heraldic lions'. This system goes some way to allowing traders and members of the public to ascertain what pictorial marks are

180. Rovio (n 19) para 68.

181. Robert Burrell and Michael Handler, 'Making Sense of Trade Mark Law' (2003) 4 IPQ 388, 408.

182. See O2 Holdings Ltd \& Anor v Hutchison 3G Ltd [2006] EWHC 534 (Ch), [2006] RPC 29 at para 80 .

183. In some cases there can be debate as to what 'sign' the defendant has used, see for example, Samuel Smith Old Brewery (Tadcaster) v Lee [2011] EWHC 1879 (Ch), [2012] FSR 7 at paras 88-91. It is possible to conceive of a case where the impugned sign is swamped or buried by other elements so that it is no longer discernible as a separate discrete sign, see British Sugar (n 53) at 294: "No-one but a crossword fanatic, for instance, would say that "treat" is present in "theatre atmosphere"'. Or there may be cases where the defendant's use complained of involves the use of a slogan or phrase, see Specsavers International Healthcare Ltd v Asda Ltd [2010] EWHC 2035 (Ch), [2011] FSR 1 at paras 127-8.

184. O2 Holdings (n 182) at para 80 and Coca-Cola v Frucor (n 60) at para 159.

185. L'Oréal SA v Bellure NV [2007] EWCA Civ 968, [2008] RPC 9 at para 110. Cf. Specsavers (n 44) at para 101 and Case C-252/12 Specsavers International Healthcare Ltd $v$ ASDA Stores ECLI:EU:C:2013:497 (discussed further below at accompanying text to $\mathrm{n} 208$ ). 186. Established by the Vienna Agreement, creating an International Classification of the Figurative Elements of Marks: Vienna, 12 June 1973 (as amended at Vienna, 1 October 1985). 
protected by inspecting the Register. ${ }^{187}$ Moreover, it is likely that technology advances will improve the ability of traders to check pictorial marks against the Register. For example, IPONZ offers a 'logo or image check' service, which helps traders check that their logo is 'safe' to use. ${ }^{188}$ However, such advances may be an unreliable mechanism for traders to ascertain whether the mark they propose to use is sufficiently conceptually distinct from a senior registered trade mark. When the conceptual attributes take on a dominant role in construing the scope of the property rights in a pictorial mark there can be an untethering of such rights from what is recorded on the Register. As explained above, identifying a concept of a trade mark can be subjective and unpredictable. ${ }^{189}$ As Wadlow has suggested: ${ }^{190}$

Defining the idea of marks allows at least as much freedom as drafting a patent claim and the basic techniques are similar: to decide which integers to include individually or in combination and how precisely each is to be constrained.

Such uncertainty and unpredictability makes it difficult for small and/or unsophisticated traders to know whether they are infringing a registered trade mark. For larger and/or sophisticated traders that can afford legal advice, the information cost of determining whether they are infringing is greatly increased - and there can still be no guarantee as to whether they will infringe.

\section{SOME CAVEATS}

\subsection{Context and acquired distinctiveness}

While it has been argued that generally adjudicators and courts should be wary of giving weight to conceptual similarity in cases involving pictorial marks, the situation may well be different if the senior registered trade mark has acquired a strong distinctive character through use in the marketplace. ${ }^{191}$ As mentioned above, the CJEU in Canon said that trade marks with a highly distinctive character enjoy broader protection. ${ }^{192}$ Further, SABEL v Puma intimated that where one trade mark had a highly distinctive character it was 'not impossible' that two marks using conceptually similar images could give rise to a likelihood of confusion. ${ }^{193}$

187. On the information and clearance costs role of the Trade Marks Register more generally, see Robert Burrell, 'Trade Mark Bureaucracies' in Graeme Dinwoodie and Mark Janis (eds), Trademark Law and Theory: A Handbook of Contemporary Research (Edward Elgar, Cheltenham 2008), 95.

188. See New Zealand Intellectual Property Office, 'About IP, Trade Marks, Search' <https:// www.iponz.govt.nz/about-ip/trade-marks/search/\#ViennaDescriptorOverview> (last accessed 1 December 2020).

189. In a related copyright context see Elwood Clothing Pty Ltd $v$ Cotton On Clothing Pty Ltd [2008] FCAFC 197, (2008) 80 IPR 566 at para 37.

190. Christopher Wadlow, The Law of Passing Off (4th edn, Sweet \& Maxwell, London 2011), para [8-056].

191. Indeed, it is often 'big brands' which are said to best placed to remove text from their logos, see O'Brien (n 7).

192. Canon (n 36) at para 18.

193. SABEL v Puma (n 38) at para 24. 
The notion that enhanced distinctiveness can lead to a higher likelihood of confusion is a controversial one. ${ }^{194}$ Pumfrey $\mathrm{J}$ has described it as 'a very surprising proposition'. ${ }^{195}$ This is because it appears possible that, at least in some circumstances, a consumer's familiarity with a trade mark with a highly distinctive character makes it less likely, rather than more likely, that consumers would be confused. ${ }^{196}$ Indeed, Australian case law has suggested that the reputation of a registered trade mark might mitigate the prospect of deceptive similarity arising from imperfect recollection. ${ }^{197}$ Nevertheless, the CJEU has continued to adhere to the principle in Canon. ${ }^{198}$

In Lloyd Schuhfabrik, the CJEU said it was not possible to precisely identify what degree of recognition a trade mark required in a marketplace to be considered as having a highly or strong distinctive character. ${ }^{199}$ An overall assessment is called for. The CJEU said this assessment should take into account the inherent characteristics of the mark, including whether it includes descriptive elements. A court or adjudicator should also take into account the same factors that go to establishing that a trade mark has acquired distinctive character sufficient for it to be registered. ${ }^{200}$ That is, enhanced distinctive character acquired by use can be evidenced by the market share held by the mark, how intensive, longstanding and geographically widespread use of the mark has been and the amount invested by the trader in promoting its mark.

The same activities that generate recognition of a trade mark within a relevant section of the public may also confer fame and notoriety on the concept or idea underlying a trade mark. Therefore, for a senior registered trade mark with acquired enhanced distinctiveness and a broader scope of protection, such notoriety and fame may justify enhanced weight being given to conceptual similarity when a comparison is made with a junior mark. Indeed, in cases where conceptual similarity tips the balance towards an overall finding that two marks are confusingly similar, the acquired, enhanced distinctiveness of the senior registered trade mark, and the idea underlying the mark, may often be a significant contributing factor. For example, in Carabao Tawandang Co Ltd v Red Bull GmbH, Red Bull GmbH's marks and brand were considered

194. See Barton Beebe and C Scott Hemphill, 'The Scope of Strong Marks: Should Trademark Law Protect the Strong More than the Weak?' (2017) 92 New York University Law Rev 1339 who critique this proposition in relation to United States trade mark law.

195. Reed Executive Plc v Reed Business Information Ltd [2002] EWHC 1015 (Ch), [2003] RPC 12 at para 103(5) but noting that it may make 'more sense' in relation to device marks. Jacob LJ in the Court of Appeal, Reed Executive (n 54) at para 83 agreed with Pumfrey J but thought that there was some truth to the opposite proposition that there is less likelihood of confusion with marks with a low level of distinctiveness. At paras 84-6 Jacob LJ described this proposition as recognizing the notion in passing off jurisprudence that small changes to a largely descriptive mark can avoid a likelihood of confusion.

196. Andrew Griffiths, 'The Impact of the Global Appreciation Approach on the Boundaries of Trade Mark Protection' (2001) 4 IPQ 326, 336.

197. See for example, Australian Meat Group Pty Ltd v JBS Australia Pty Ltd [2018] FCAFC 207, (2018) 268 FCR 623 at para 41; Mars Australia Pty Ltd v Sweet Rewards Pty Ltd [2009] FCA 606, (2009) 81 IPR 354 at para 98(b); CA Henschke \& Co v Rosemount Estates Pty Ltd [2000] FCA 1539, (2000) 52 IPR 42 at para 52.

198. Fhima and Gangjee (n 33) 137.

199. Lloyd Schuhfabrik (n 67), at para 24.

200. Ibid, at para 23 applying the factors laid out by the CJEU in Joined Cases C-108/97 and C-109/97 Windsurfing Chiemsee Produktions-und Vertriebns GmbH v Boot-und Segel-zubehör Walter Huber [1999] ECR I-2779, ECLI:EU:C:1999:230 at para 51. 

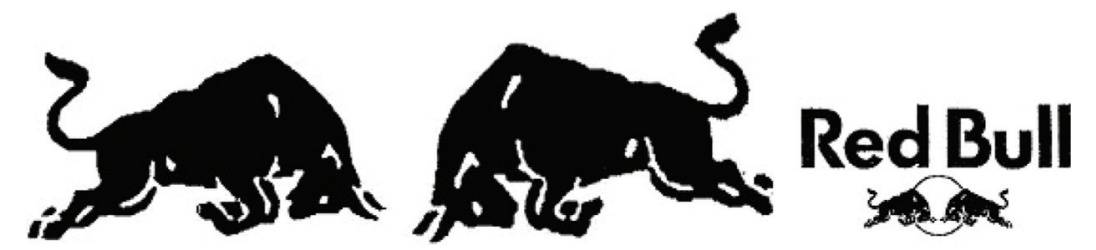

Figure 17 New Zealand Trade Mark Registration Nos. 251973, 304484 and 610902

well-known, and Red Bull GmbH provided evidence that the 'concept or idea of a "Bull" was "central to its promotional activities'.201

Moreover, evidence that serves to accentuate the idea of the mark may be particularly relevant in an opposition context where the senior registered mark owner owns a 'family' of related marks. This appears to have also been relevant in Carabao Tawandang Co Ltd $v$ Red Bull GmbH. Not only did Red Bull GmBH rely on the image marks shown in Figure 17, but it also relied on the word marks RED BULL and BULL.

Similarly, in Glenn Elliott v Heineken Asia Pacific Pte Ltd, Heineken Asia Pacific Pte Ltd was able to rely on the word mark TIGER and a range of pictorial marks, including those set out in Figure 18 and in Figure 12.202

Arguably there is a greater propensity for the fame or notoriety of an idea, evidenced by use of a trade mark or use of a family of trade marks in the marketplace, to be relevant in opposition proceedings under New Zealand law. ${ }^{203}$ The most common ground of opposition under the 2002 Act is s 17(1)(a), and this section is generally considered first. Section 17(1)(a) considers a likelihood of confusion or deception having regard to the reputation acquired by the opponent's senior registered trade mark. ${ }^{204}$ Consideration of the degree of similarity between the senior mark, as used, ${ }^{205}$ and the junior mark, as applied for, is built into an assessment of a likelihood of confusion or deception. ${ }^{206}$ Given the focus on how the senior mark is used, this is a different approach than that taken under the relative grounds (and in respect of the approach taken to assessing infringement) and gives scope to consider how features of a trade mark have been emphasized in marketing or in promotional activities. However, generally the same principles that are used to assess the similarity of marks are applied under s 17(1)(a). As a result, the outcome of the assessment of similarity under s 17(1)(a) (which is usually arrived at first) generally dictates the analysis of similarity under the relative ground of refusal under s $25 .^{207}$

201. Carabao Tawandang (n 170) at paras 17-18.

202. Glenn Elliott (n 150).

203. But cf. in an infringement context Coca-Cola v Frucor (n 60) at paras 159-60.

204. The usual test applied comes from Smith Hayden \& Co Ltd's Application (1946) 63 RPC 97 at 101.

205. Pharmazen (n 90) at para 35.

206. Sexwax Inc v Zoggs International Ltd [2014] NZCA 11, [2015] 2 NZLR 1 at para 49. Though importantly, in Man Truck \& Bus AG v Shaanxi Heavy-Duty Automobile Co Ltd [2017] NZHC 2821 at para 38, Woodhouse J pointed out that similarity is not a requirement under s 17(1)(a), but only relevant to the assessment of a likelihood of confusion. Therefore, 'substantive dissimilarity cannot be determinative'.

207. See for example, Carabao Tawandang (n 170) at para 60: 'Turning now to ss 25(1)(b) and (c), and based essentially on the reasoning outlined above as regards s 17 , I find that the appellant's CARABAO mark is similar to the relevant marks of the respondent and that its use is likely to deceive'. 

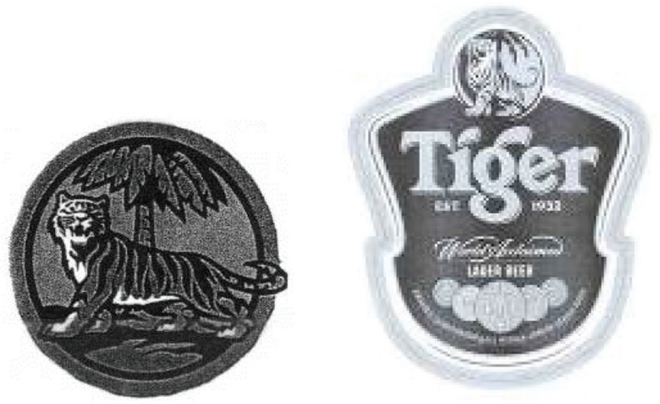

Figure 18 New Zealand Trade Mark Registration Nos. 613836 and 742713

In Specsavers International Healthcare v Asda Stores the CJEU also indicated that there was room within the global assessment approach to take into account how a senior registered trade mark had been used when determining infringement. ${ }^{208}$ In that case, the registered trade mark was filed in black and white, which is typically taken as covering use in all colours. However, the CJEU said that when determining infringement it was relevant that the owner had used the sign covered by its registration in green and the defendant had also used the same colour. ${ }^{209}$ This seems to leave it possible in infringement proceedings for courts to consider if use of a registered trade mark in a particular way has enhanced the idea of a trade mark. However, as Fhima and Gangjee suggest, it is unlikely that courts will deviate too far from the Register as the reference point for determining the scope of protection of a senior registered trade mark. ${ }^{210}$ For example, subsequently in JW Spear \& Sons Ltd v Zynga Floyd LJ in the English Court of Appeal rejected the contention that account had to be taken of matter that is 'routinely and uniformly used in association with' the senior registered trade mark. ${ }^{211}$

In Il Ponte Finanziaria SpA v OHIM the CJEU also held that it was permissible to consider a 'family' of marks possessing common characteristics when considering a likelihood of confusion. ${ }^{212}$ However, the CJEU indicated that the status of marks as a 'family of marks' is only conferred through marketplace use which would lead consumers to recognize the marks as part of a family. ${ }^{213}$ On this basis, if a trade mark owner can establish a reputation associated with a family of marks used in the marketplace with the same or a similar idea, this is likely to significantly strengthen a claim for confusing similarity based predominantly on conceptual similarity. ${ }^{214}$

208. Case C-252/12 (n 185).

209. Ibid at [37]-[38].

210. Fhima and Gangjee (n 33) 189.

211. JW Spear \& Sons Ltd v Zynga Inc [2015] EWCA Civ 290, [2015] FSR 19 at para 47 also cited in Fhima and Gangjee (n 33) 189.

212. Il Ponte Finanziaria SpA v OHIM [2007] ECR I-07333, ECLI:EU:C:2007:514 at paras 62-4. The same principle was applied in Infamous Nut (n 147) at para 37: 'In some circumstances, it may be possible for the opponent to argue that an element in the earlier trade mark has achieved enhanced distinctiveness in the eyes of the public because it is common to a "family of marks" in the proprietorship and use of the opponent'.

213. Il Ponte Finanziaria SpA v OHIM [2007] ECR I-07333, ECLI:EU:C:2007:514 at para 64. 214. For the Singapore position, see McDonald's Corp v Future Enterprises Pte Ltd [2004] SGCA 50, [2005] 1 SLR(R). 
In infringement proceedings there may also be circumstances in which the context of the defendant's use may make it more appropriate that conceptual similarity should be weighted towards finding a likelihood of confusion. This flows from the CJEU's judgment in $O 2$ (UK) Ltd v Hutchison $3 G$ Ltd. ${ }^{215}$ The previous position in the United Kingdom was exemplified by the strict approach outlined in Saville Perfumery Ltd $v$ June Perfect Ltd. ${ }^{216}$ In that case it was held that the comparison to be undertaken in determining infringement was between the senior registered trade mark and the mark used by the defendant, and the defendant could not escape infringement 'by showing that by something outside the actual mark itself he has distinguished his goods from those of the registered proprietor' ${ }^{217}$ However, in $O 2$ Holdings the CJEU intimated that regard should be had to the 'context' and 'characteristics' of the defendant's use. ${ }^{218}$ Subsequently, in Specsavers Kitchen LJ interpreted the CJEU's judgment as altering the strict approach in Saville Perfumery and indicated that one must: 219

... take into account all the circumstances of that use that are likely to operate in that average consumer's mind in considering the sign and the impression it is likely to make on him. The

sign is not to be considered stripped of its context.

It remains equivocal as to the precise ambit of the 'context' of the defendant's use that may be taken into account. ${ }^{220}$ However, it is possible to envisage situations, such as a television advertisement, where images, text or audio accentuate or reinforce similarity with the concept or idea of the senior registered trade mark.

Singaporean courts have been more circumspect in taking into account the context of a defendant's use. In Polo/Lauren Co, LP v Shop In Department Store Pte Ltd the Court of Appeal confirmed that 'extraneous factors' could be taken into account in determining infringement, including steps taken by the defendant to differentiate its goods or services. ${ }^{221}$ However, in Hai Tong Co (Pte) Ltd v Ventree Singapore Pte Ltd the Court of Appeal clarified that such extraneous factors should be limited to those that impact on the similarity of the marks or the similarity of the goods or services. $^{222}$ In Staywell the Court of Appeal reiterated this analysis and held that 'impermissible' extraneous factors are those that are not inherent in the goods, but those which could be changed by a trader from time to time. ${ }^{223}$

In New Zealand the current position in respect of infringement follows the 'mark for sign' approach of Saville Perfumery. ${ }^{224}$ In Coca-Cola v Frucor the defendants argued that, following United Kingdom and European authorities, the law should

215. Case C-533/06 (n 34).

216. Saville Perfumery Ltd v June Perfect Ltd (1941) 58 RPC 147.

217. Ibid at 161 .

218. At [64]-[67] .

219. Specsavers $(\mathrm{n} 44)$ at para 87.

220. See Och-Ziff Management Europe Ltd \& Och Capital LLP [2010] EWHC 2599 (Ch), [2011] FSR 11 at paras 77 to 78 and Gangjee and Fhima (n 33) 192.

221. Polo/Lauren Co (n 57) at para 28.

222. Hai Tong (n 40) at para 87. See also Tee Jim Tan SC (n 30) 667.

223. Staywell (n 34) at para 95.

224. In Levi Strauss \& Co v Kimbyr Investments Ltd [1994] 1 NZLR 332 at 363 (a case under the Trade Marks Act 1953) it was said that: 'The plaintiffs' mark as registered must be compared with the defendant's mark as it appears in actual use. Additions or variations which may be relevant in a claim for passing-off will not avoid a trade mark infringement claim'. See also Anheuser-Busch (n 90) at para 109. 
move away from the strict approach in Saville Perfumery. The defendants argued that the comparison in the case should be between Coca-Cola Co's registered trade marks that related to the shape of its bottle, and the defendants' bottle together with the word marks and device marks that featured on the defendants' bottle. Wylie J, though, was not persuaded that such authorities were of assistance in interpreting New Zealand's legislation. Wylie J held that the defendants were using the impugned bottle's shape as a sign, and that in considering whether this sign infringed Coca-Cola Co's registered trade marks, the additional word and device marks that featured on the impugned bottle had to be disregarded. ${ }^{225}$ However, given the influence of European jurisprudence and the desire to interpret New Zealand's legislation in accordance with the position in Europe and the United Kingdom, ${ }^{226}$ the context of a defendant's use may become increasingly relevant in infringement proceedings.

\subsection{Evidence of confusion and the average consumer}

A second important caveat to the argument that conceptual similarity should not be overweighted is a situation where there is evidence of actual confusion between the junior mark applied for and a senior registered trade mark, or between a senior registered trade mark and the sign used by a defendant. It is not necessary for the owner of a registered trade mark to succeed in an infringement action or an opposition proceeding to establish that consumers have actually been confused. ${ }^{227}$ Moreover, courts are also cognizant that a lack of evidence of actual confusion is not necessarily proof that a registered trade mark and junior mark are not sufficiently similar to give rise to a likelihood of confusion. ${ }^{228}$ However, evidence of actual confusion is often persuasive that there is a continued likelihood of confusion. ${ }^{229}$ Conversely, a lack of evidence of confusion may, in some circumstances, tip the balance against a finding of a likelihood of confusion. $^{230}$

It is, though, probably rare that evidence of consumer confusion would be viewed as helpful in cementing a conclusion that confusion is likely because of conceptual similarity between the junior mark applied for and a senior registered trade mark, or between the senior registered trade mark and the sign used by the defendant. The usual evidence put forward in trade mark cases takes the form of expert evidence, evidence from individual consumers and survey evidence. English courts, in particular, have been hostile to expert evidence ${ }^{231}$ and survey evidence. ${ }^{232}$ As Millet LJ remarked in respect of those giving expert trade evidence - 'they are experts in the market, not on confusing similarity'. ${ }^{233}$ In some cases, such as Comic Enterprises Ltd $v$ Twentieth Century Fox, it has been found that the 'spontaneous evidence of members of the

225. Coca-Cola v Frucor (n 60) at para 123.

226. See comments to this effect in Leisureworld Ltd $v$ Elite Fitness Equipment Ltd HC Auckland, CIV 2006-404-3499, 21 July 2006 at para 96; International Consolidated Business Proprietary Ltd v SC Johnson \& Son Inc [2020] NZSC 110 at para 33.

227. Och-Ziff (n 220) at para 117.

228. Maier v ASOS Plc (n 44) at para 80 and Compass Publishing BV v Compass Logistics Ltd [2004] EWHC $520(\mathrm{Ch})$, [2004] RPC 41 at para 22.

229. General Electric Co Ltd (USA) v General Electric Co Ltd [1972] 1 WLR 729 at 737.

230. Hannaford (n 100) at 20.

231. See esure Insurance (n 60).

232. See Interflora Inc v Marks and Spencer Plc (No 2) [2013] EWCA Civ 319, [2013] FSR 26.

233. The European Ltd (n 4) at 291. 
public' may be helpful in assessing a likelihood of confusion. ${ }^{234}$ However, in that case the Court was careful to signal that the assessment of whether use of a junior mark is likely to cause confusion has to be determined by reference to the 'average consumer', and any such evidence must be evaluated to ensure it is truly representative of the average consumer. ${ }^{235}$

Moreover, the average consumer is not an empirical measure. Rather, the average consumer has been described as a 'legal construct' (which can be informed, to an extent, by empirical evidence of consumer perception). ${ }^{236}$ As Kitchin LJ said in Interflora $v$ Marks \& Spencer, the average consumer ${ }^{237}$

... has been created to strike the right balance between various competing interests including, on the one hand, the need to protect consumers and, on the other hand, the promotion of free trade in an openly competitive market ...

In the area of assessing a likelihood of confusion, adopting the mantle of the average consumer provides courts with the latitude to normatively consider whether confusion or a likelihood of confusion caused by the similarity of marks suffices to 'warrant the court's intervention'. ${ }^{238}$ It is suggested that courts should be slow to find that conceptual similarity alone is sufficient to justify the owner of a registered pictorial mark excluding others from utilizing the same idea in the marketing of their own goods and services.

\section{CONCLUSION}

Using illustrative examples from United Kingdom, Singapore and New Zealand case law, this article has demonstrated the difficulties of ascertaining the appropriate scope of protection for a registered pictorial mark. It has been argued that when infringement or opposition proceedings are launched in reliance on a pictorial mark there is a risk of adjudicators overweighting conceptual similarity. This risk, if manifested, can undesirably enlarge the scope of protection given to the pictorial mark. In particular, overweighting conceptual similarity may risk awarding the first registrant of a pictorial mark a monopoly over an idea in a particular commercial sphere. It may also untether protection from what is represented on the Trade Marks Register.

In light of such difficulties and the associated risks, this article has demonstrated how courts and adjudicators should exercise care in assessing conceptual similarity between a senior registered pictorial mark and a junior mark. First, circumspection should be exercised by identifying the idea of a pictorial mark at an appropriately low level of abstraction. For instance, the idea associated with an image of a member

234. See Comic Enterprises Ltd v Twentieth Century Fox [2016] EWCA Civ 41, [2016] ECC 24 at para 42.

235. Ibid at para 42. Particularly where the goods and services are not of an ordinary type, evidence may be relevant to inform the court of the fact and circumstances an average consumer would know, see Bach and Bach Flower Remedies Trade Marks [2000] RPC 513 at 535.

236. Interflora Inc v Marks and Spencer Plc (No. 2) [2012] EWCA Civ 1501, [2013] FSR 21 at paras 44 and 73. See also Interflora Inc v Marks and Spencer Plc [2014] EWCA Civ 1403, [2015] FSR 10 at para 113.

237. Interflora Inc v Marks and Spencer Plc [2014] EWCA Civ 1403, [2015] FSR 10 at para 113.

238. Ibid at para 129. See also The European (n 4) at 288: 'A degree of similarity is tolerable; the question is whether there is a confusing similarity'. 
of the crocodilian species should be identified with sufficient specificity which takes into account the precise subject matter, pose/activity and style of the image. Second, circumspection should be exercised by paying close regard to the distinctiveness and imaginative content of a potentially shared idea. For example, an image of a bird with 'accoutrements suggestive of an English gentleman', ${ }^{239}$ a monkey playing a piano ${ }^{240}$ or a puma playing a violin ${ }^{241}$ might be considered to convey highly distinctive ideas in relation to clothing (or indeed most other products). A junior mark representing the same basic idea may inevitably trigger a finding of similarity. By contrast, a mark comprising an image of a bird, monkey or puma that is merely representational of such an animal's natural features may convey a less distinctive idea. The protection given to such a mark in light of other marks that present a similar idea should be construed more narrowly. Third, and relatedly, courts and adjudicators should be reluctant to treat the idea of a pictorial mark as its central message or essential element particularly when the idea is not fanciful or distinctive. Such an approach may ignore important visual differences between trade marks. For instance, consider the visual differences between, and the co-existence of, various horse logos in the automotive industry, such as those used by Ferrari, Porsche, Ford (ie on the Mustang series) and Bajoun. ${ }^{242}$

Despite the above suggestions, it must be stressed that trade mark cases are inherently dependent on the particular circumstances. Examples from previous cases cannot, and should never, be seen as providing definitive guidance. Moreover, given that the scope of protection of a registered trade mark is shaped by a likelihood of consumer confusion, evidence of actual consumer perception in the particular case may always be relevant. However, assessing a likelihood of confusion is not an entirely empirical exercise. As Jacob LJ has remarked, it involves 'a value judgment to be drawn from all the circumstances' ${ }^{243}$ In determining the role of shared conceptual similarity between a senior pictorial mark and a junior mark, it is suggested that courts and adjudicators should bear in mind that trade mark law does not seek to protect ideas as such, and the assessment of a likelihood of confusion between two trade marks should be tailored to ensure trade mark law does not confer monopolies in ideas.

239. See Jack Wills (n 96) at para 94.

240. See Baker Street (n 113) at para 26(6).

241. See SABEL v Puma (n 38), Opinion of AG Jacobs ECLI:EU:C:1997:221 at para 61.

242. See 'Car Logos with Horse' 1000 Logos (14 September 2020) <https://www.1000logos. net/car-logos-with-horse/> (last accessed 29 January 2021) and also Earl Gray, Richard Watts and Janelle Simpson, "It's All About the Crocodile ...": Court of Appeal puts New Zealand Trade Mark Law into a Tail Spin ...', Simpson Grierson (13 April 2016) <https://www.simpsongrierson.com/articles/2016/crocodile-lacoste-court-of-appeal-nz-trade-mark-law> (last accessed 29 January 2021).

243. Reed Executive (n 54) at para 82. 